University of Chicago Law School

Chicago Unbound

Journal Articles

Faculty Scholarship

1983

\title{
The Constitution in the Supreme Court: Contracts and Commerce, 1836-1864
}

David P. Currie

Follow this and additional works at: https://chicagounbound.uchicago.edu/journal_articles

Part of the Law Commons

\section{Recommended Citation}

David P. Currie, "The Constitution in the Supreme Court: Contracts and Commerce, 1836-1864," 1983 Duke Law Journal 471 (1983).

This Article is brought to you for free and open access by the Faculty Scholarship at Chicago Unbound. It has been accepted for inclusion in Journal Articles by an authorized administrator of Chicago Unbound. For more information, please contact unbound@law.uchicago.edu. 


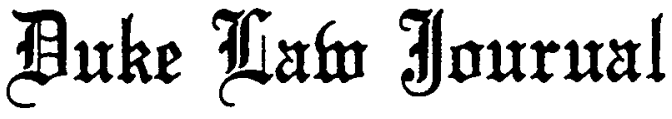

\begin{tabular}{lll}
\hline VOLUME 1983 & JUNE & NUMBER 3 \\
\hline
\end{tabular}

\section{THE CONSTITUTION IN THE SUPREME COURT: CONTRACTS AND COMMERCE, I836-I864}

\author{
DAVID P. CuRriE*
}

Continuing a study of the first hundred years of constitutional litigation, Professor Currie explores the decisions of the Taney period respecting the Contract and Commerce Clauses. Though early decisions of the Taney Court seemed to portend a departure from the nationalism of its predecessor, the author argues that the impression was largely misleading. In general, for example, the Court under Taney proved rather sympathetic to contract rights. In Commerce Clause cases, after being badly split, the Court was able to agree on a longlasting formula that acknowledged an implicit limitation on state power; and although in the Taney period the Court never clearly struck down a state law on Commerce Clause grounds, it found other ways to protect the interest in unobstructed commerce.

The fourth installment of a critical examination of early Supreine Court constitutional decisions, ${ }^{1}$ this article begins to deal with the nearly thirty-year period during which Roger B. Taney was Chief Justice. Taney's appointment in 1836 inarked a watershed in the inember-

- Harry N. Wyatt Professor of Law, University of Chicago. My thanks to the Duke University School of Law, where this paper was delivered as the Brainerd Currie Memorial Lecture; to my colleagues Frank Easterbrook, Dennis Hutchinson, and Rayman Solomon for their helpful criticism; and to Mark Holmes and Roy Underhill for valuable research assistance.

1. See Currie, The Constitution in the Supreme Court, 1789-1801, 48 U. CHI. L. REv. 819 (1981) [hereinafter cited as Currie, Supreme Coun, 1789-1801]; Currie, The Constitution in the Supreme Court: The Powers of the Federal Courts, 1801-1835, 49 U. CHI. L. ReV. 646 (1982) [hereinatter cited as Currie, Federal Courts, 1801-1835]; Currie, The Constitution in the Supreme Court: State and Congressional Powers, 1801-1835, 49 U. CHI. L. REv. 887 (1982) [hereinafter cited as Currie, States and Congress, 1801-1835]. 
ship of the Court. ${ }^{2}$ President Jackson had appointed three new Justices in the seven years before Taney: John McLean, Henry Baldwin, and Jaines M. Wayne. Within a year, Jackson and President Van Buren were to appoint three more: Philip P. Barbour, John Catron, and John McKinley. ${ }^{3}$ Of the Justices who sat with Marshall before 1829 , only Joseph Story and Smith Thompson remained. Thus, from nearly the beginning of his tenure, Taney presided over an almost entirely new Court, one with seven members appointed by Jackson and Van Buren. It was an opportunity for a fresh start.

Taney's term stretched from the age of Jackson until almost the end of the Civil War. Twenty Justices sat during these twenty-eight years. Four of Taney's original brethren - Barbour, Baldwin, Thompson, and Story - left the Court between 1841 and 1845. During the next fifteen years, as in the middle days of Marshall, ${ }^{4}$ the Court enjoyed a notable stability in membership. Seven Justices sat together

2.

Justices of the SUPReme Court during the Chief Justiceship of Roger B. TANey

\begin{tabular}{|c|c|c|c|c|c|c|c|c|}
\hline & & 1835 & 1840 & 1845 & 1850 & 1855 & 1860 & 1865 \\
\hline Joseph Story & $(1811-1845)$ & & & & & & & \\
\hline Smith Thompson & $(1823-1843)$ & & & & & & & \\
\hline John McLean & $(1829-1861)$ & & & & & & & \\
\hline Henry Baldwin & $(1830-1844)$ & & & -1 & & & & \\
\hline James M. Wayne & $(1835-1867)$ & & & & & & & \\
\hline Roger B. Taney & $(1836-1864)$ & & & & & & & \\
\hline Philip P. Barbour & $(1836-1841)$ & & & & & & & \\
\hline John Catron & $(1837-1865)$ & & & & & & & \\
\hline John McKinley & $(1837-1852)$ & & & & & & & \\
\hline Peter V. Damiel & $(1841-1860)$ & & & & & & & \\
\hline Samuel Nelson & $(1845-1872)$ & & & & & & & \\
\hline Levi Woodbury & $(1845-1851)$ & & & & & & & \\
\hline Robert C. Grier & $(1846-1870)$ & & & & & & & \\
\hline Benjamin $\mathbf{R}$. & & & & & & & & \\
\hline Curtis & $(1851-1857)$ & & & & & & & \\
\hline John A. Campbell & $(1853-1861)$ & & & & & & & \\
\hline Nathan Chifford & $(1858-1881)$ & & & & & & & \\
\hline Noah H. Swayne & $(1862-1881)$ & & & & & & & \\
\hline Samuel F. Miller & $(1862-1890)$ & & & & & & & \\
\hline David Davis & $(1862-1877)$ & & & & & & & \\
\hline Stephen J. Field & $(1863-1897)$ & & & & & & & \\
\hline
\end{tabular}

(Adapted from G. Gunther, Cases and Materlals on Constitutional Law app. A, at A-2, A-3 (10th ed. 1980)).

3. Congress created two new seats on the Court by the Act of Mar. 3, 1837, ch. 34, \& 1, 5 Stat. 176, 176 (current version at 28 U.S.C. $\$ 1$ (1976)). A number of new states had been without circuit justices and thus without circuit courts before this expansion. See 5 C. SWISHER, HISTORY of the SUPREME COURT OF the UNITEd STATES 58 (1974).

4. See Currie, Federal Courts, 1801-1835, supra note 1, at 647. 
from 1846 to 1860: Taney, McLean, Wayne, Catron, Peter V. Daniel, Samuel Nelson, and Robert C. Grier. McKinley, Levi Woodbury, Benjamin R. Curtis, and John A. Campbell effectively completed the roster during this period. The remaining five Justices-Nathan Clifford, Noah H. Swayne, Samuel F. Miller, David Davis, and Stephen J. Field-appeared only briefly at the end of Taney's Chief Justiceship, as forerunners of the next change in Court membership. Taney's tenure ended as it began, with a whole generation of Justices ending their careers at nearly the same time.

Accomplishments sometimes end before careers, however, and the Supreme Court had been in a somewhat suspended state before Taney appeared on the scene. The bulk of Marshall's architectural workfederal judicial power to protect federal rights, congressional authority to regulate navigation and establish a bank, and significant limitations on state legislative power-had been completed by about $1825 . .^{5} \mathrm{New}$ Justices like McLean, Baldwin, and Thompson broke more frequently with the Marshall consensus, taking a less restrictive view of limitations on state authority. As the absences of Justices Gabriel Duvall and William Johnson increased, three major constitutional cases were deferred due to mability to muster a majority of the full Court. In 1835 and 1836 three vacancies occurred, 6 and the Court decided no important constitutional cases.

The new day dawned with a bang in 1837, when the three big cases so long postponed were finally decided: New York v. Miln, ${ }^{7}$ Briscoe v. Bank of Kentucky, ${ }^{8}$ and Charles River Bridge v. Warren Bridge. ${ }^{9}$ Each concerned limitations on state power, in each the Court upheld state authority; in each Story wrote an impassioned dissent lamentimg the dismantling of all that Marshall had built. Despite a flock of Republican appointments, Jefferson and Madison had failed to dislodge the Federalist philosophy from its last citadel in the courts; Jackson and Van Buren now had apparently succeeded.

Overall, however, the 1837 decisions proved to have created a false impression. In certam respects the Court contimued to be somewhat more solicitous of state authority under Taney than it had been under Marshall. Yet Taney and his brethren not only wielded the contract clause with considerable vigor to protect vested rights agamst state im-

5. See generally Currie, Federal Courts, 1801-1835, supra note 1; Currie, States and Congress, 1801-1835, supra note 1.

6. See generally G. GUNTHER, supra note 2, app. A, at A-2, A-3.

7. 36 U.S. (11 Pet.) 102 (1837).

8. 36 U.S. (11 Pet.) 257 (1837).

9. 36 U.S. (11 Pet.) 420 (1837). 
pairment, but also (with one notorious exception) forcefully extended the limits of federal legislative and judicial power. None of this was accomplished with the unanimity that had characterized the best days of Marslall; repeated dissents by true states'-righters like Campbell and Daniel highlighted just how far from that category Taney and most of his colleagues were. At the same time, Taney abandoned Marshall's insistence on writing nearly everything himself; accordingly, we shall examine the judicial product of quite a number of Justices. ${ }^{10}$

\section{Beginnings: The Three Bombshells of 1837}

\section{A. New York v. Miln.}

As part of a sclreme for preventimg immigrants from becoming public charges, a New York statute required ship captains to furnish local authorities with a list of all passengers they brought into the state. ${ }^{11}$ Over Story's dissent, the Court held that this requirement did not conflict with Congress' power to regulate foreign cominerce. ${ }^{12}$

Four Marshall decisions had touched on the negative effects of the commerce clause on state authority, but none had clearly struck down a state law on commerce clause grounds. Gibbons $v$. Ogden ${ }^{13}$ had invalidated a state steaniboat inonopoly; Brown v. Maryland ${ }^{14}$ had set aside a tax on the privilege of selling imported goods in their origmal package; Worcester v. Georgia ${ }^{15}$ had held the state could not prohibit whites from living on the Clierokee Reservation; Willson v. Black Bird Creek Marsh Co. ${ }^{16}$ had allowed the damming of a navigable stream. The first three cases variously intimated that the cominerce clause might have a

10. The best general Court histories of the period as a whole are 5 C. Swisher, supra note 3 , and 2 C. Warren, The Supreme Court in United States History (rev. ed. 1932). Biographies of Justices of the time include H. ConNoR, JoHN ARChIBald Campbel. (1920); Curtis, Memoir of Benjamin Robbins Curtis, LL. D., in 1 A MemolR OF BENJaMin RobBins CuRTis (B.R. Curtis, Jr. ed. 1879 \& photo reprint 1970); G. DUNNE, Justice JosepH STORY AND THE RISE OF the Supreme Court (1970); J. Frank, Justice Daniel. Dissenting (1964); A. LaWrence, James Moore Wayne, Southern Unionist (1943); J. McClellan, Joseph Story and the American Constitution (197I); C. Swisher, Roger B. TANEY (1935); F. Weisenburger, The LIFE OF JOHN MCLEAN (1937).

11. Act of Feb. 11, 1824, ch. 37, 1824 N.Y. Laws 27.

12. New York v. Miln, 36 U.S. (11 Pet.) 102 (1837). The statute also required the master to post a bond to cover expenditures if the immigrant became a public charge, and to remove him from the country in sucli event. Act of Feb. 11, 1824, ch. 37, $\$ \S$ II, III, 1824 N.Y. Laws 27, $27-28$. The suit in Miln did not involve these provisions, and the Court did not rule on them. See Miln, 36 U.S. (II Pet.) at 144-45 (Thoupson, J., concurring).
13. 22 U.S. ( 9 Wheat.) 1 (1824).
14. 25 U.S. (12 Wheat.) 419 (1827).
15. 31 U.S. (6 Pet.) 515 (1832).
16. 27 U.S. (2 Pet.) 245 (1829). 
negative effect of its own, but each also recited alternative grounds of decision. In Willson, stressing that no federal statute forbade construction of the dam, Marshall concluded that the law in question could not, "under all the circumstances of the case, be considered as repugnant to the power to regulate commerce in its dormant state."17

All four Justices who wrote in Miln took these precedents quite seriously. ${ }^{18}$ Barbour, a "states-right's Virginian"19 appointed just the year before Miln, wrote for the Court a relatively straightforward opinion leaving open the question whether Congress possessed exclusive authority to regulate commerce. ${ }^{20}$ The Court had already acknowledged in Gibbons that the states could constitutionally affect commerce by such exercises of the police power as quarantine and inspection laws; ${ }^{21}$ the law requiring a passenger list was similarly a police measure designed to protect the welfare of New Yorkers by keeping down the tax burden. ${ }^{22} \mathrm{~A}$ state had as much right to guard against "the moral pestilence of paupers, vagabonds, and possibly convicts," Barbour added crudely, as against "the physical pestilence" of infected crews and cargo. ${ }^{23}$ Thompson's literate concurrence added a citation to Willson, in which Marshall had apparently elevated his police power dictum into a holding. ${ }^{24}$ Thompson also questionably took Willson as authority that Congress' power to regulate commerce itself was not exclusive. 25

17. Id. at 252. For discussion of these cases, see Currie, States and Congress, 1801-1835, supra note 1, at 938-56.

18. The official report contains the opinions of Barbour, Thompson, and Story. Miln, 36 U.S. (11 Pet.) at 130, 143, 153. Baldwin later published a separate opinion. See infro note 25. For the Marshall Courr's contrasting tendency to ignore precedent, see Currie, States and Congress, 18011835, supra note 1, at 972-73.

19. See C. SwisHER, supra note 10, at 139, 360, 5 C. SwISHER, supra note 3, at 56.

20. Miln, 36 U.S. (11 Pet.) at 132.

21. Id. at 133, 141-42 (citing Gibbons); see Gibbons, 22 U.S. (9 Wheat) at 205 (Marshall, C.J.). For criticism of this distinction as an original matter, see Currie, States and Congress, 1801 1835, supra note 1, at 945-46.

22. Miln, 36 U.S. (11 Pet.) at 141. New York had passed the law, wrote Barbour, "to prevent her citizens from being oppressed by the support of multitudes of poor persons . . . [without] the means of supporting themselves." Id.

23. Id. at 142-43. In distinguishing Brown v. Maryland, Barbour added unnecessarily that, unlike goods, persons "are not the subject of commerce." Id at 136. This remark was later to be the focus of serious controversy within the Court. See infra text accompanying notes 227-29 (discussing the Passenger Cases).

24. See Willson, 27 U.S. (2 Pet.) at 149-50; Currie, States and Congress, 1801-1835, supra note 1 , at 946-47.

25. Miln, 36 U.S. (11 Pet.) at 149-53. Thompson expressly refrained from deciding the extent of Congress' power over commerce, but at one point he seemed to suggest Congress might lack capacity to legislate with respect to passengers already landed. Id. at 146-47. Baldwin later made the same point explicitly in a long and boring stateinent. See 36 U.S. (11 Pet.) at 152-53o (3d ed. 1884), originally published in H. BALDWIN, A GENERAL VIEW OF THE ORIGIN AND NATURE OF 
In dissent, Story agreed that the states could affect commerce by exercising their police powers and seemed to concede that therefore they could exclude paupers. ${ }^{26} \mathrm{He}$ argued, however, that the passenger list requirement did more than affect commerce: it regulated commerce itself, namely "the conduct of masters, and owners and passengers, in foreign trade." 27 Though the states might pass health laws and other police power measures, said Story, they "cannot make a regulation of commerce, to enforce" them, ${ }^{28}$ for Gibbons had settled that Congress had exclusive power to regulate commerce. ${ }^{29}$

Gibbons, of course, had settled no such thing. As Thompson poimted out im his concurrence, ${ }^{30}$ Gibbons held only that state law must yield when it contradicted a federal statute-Marshall's suggestions about the exclusivity of the commerce power were obiter as well as inconclusive. ${ }^{31}$ Moreover, Story's position seens inconsistent both with his own concessions about the exclusion of paupers and with Marshall's discussion of quarantine laws in Gibbons. A law excluding paupers or quarantiming vessels is no less a regulation of commerce than is a requirement that the master provide a passenger list. Indeed, as Barbour noted, ${ }^{32}$ the statute in Miln required delivery of the list after the passengers landed, while the quarantine and exclusion laws interrupted transportation itself. If such interruptions are acceptable because they are enacted under the police power label, the list requirennent should be

THE Constitution ANd Government of the United States 181 (1837), reprinted in 9 L. Ed. 961 (1883 ed.). Baldwin explained that later events had caused him to abandon his "intention" of "a silent concurrence," and that he had also abandoned a plan to publish the opinion "in an appendix" to the official reports. See 9 L. Ed. at 873, 928. It thus is unclear whether Baldwin ever considered the statement an actual concurring opinion. Cf. 2 C. HAINES \& F. SHERwOOD, THE Role of the SUPReme Court in AMERICAN Government and Politics 1835-1864, at $46 \mathrm{n} .61$ (1957) (statement "accidentally omitted").

Justice Wayne later asserted that Thompson, initially assigned to write for the Court, could not secure the needed majority "on account of some expressions . . . concerning the power of Congress to regulate commerce." Passenger Cases, 48 U.S. (7 How.) 283, 431 (1849) (separate opinion).

26. Miln, 36 U.S. (11 Pet.) at 156.

27. Id at 157 .

28. Id. at 156.

29. Id at 158. Story also argued the state law was contrary to federal statutes he read as "authoriz!ing] . . . the introduction of passengers into the country." Id at 158-59. As both Barbour and Thompson noted, however, these statutes seemed remote from the issue: they regulated shipboard safety and required detivery of passenger lists to federal authorities for customs and census purposes. Id at $138,146$.

30. Id:at 145.

31. See Currie, States and Congress, 1801-1835, supra note 1, at 942-46.

32. Miln, 36 U.S. (11 Pet.) at 142. 
too. 33

Story stood alone in dissent, but he invoked his departed leader for support. Marshall had heard the arguments before he died and had agreed, said Story, that the New York law fell "directly within the principles established" by Gibbons and Brown v. Maryland. ${ }^{34}$ This remarkable breach of the confidentiality of Court deliberations has led at least one commentator to accuse Story of misrepresenting Marshall's position. ${ }^{35}$ None of Marshall's other former colleagues stepped up to dispute Story's account, however; more likely, the Chief Justice had begun to regret his broad concessions to the states' police power.

Even if Story was right that Marshall would have joined his dissent in Miln, the majority opinion does not seem to represent the sudden break with Marshall's earlier jurisprudence that Story claimed. On the contrary, the inajority seems to have apphed Marshall's own declared primciples fairly and accurately to sustam state power in an easy case. ${ }^{36}$

\section{B. Briscoe v. Bank of Kentucky.}

The Bank of Kentucky, a corporation owned and controlled by the state, issued a negotiable instrument payable to the bearer in exchange for Briscoe's promissory note. When the Bank sued to collect on the note, Briscoe defended on grounds of illegal consideration, arguing that the instrument issued by the bank had offended the provision of article I, section 10, that "[n]o State shall . . . emit Bills of Credit."37 The state courts rejected this argument, and the Supreme Court affirmed, once again over Story's solitary dissent. ${ }^{38}$

As in Miln, the Court's opmions dealt largely with precedent. Only

33. One of the weaknesses of Marshall's thesis was that the police power concept was hardly self-defining. The Court made no serious effort in Miln or elsewliere to define it, but even Story's dissent conceded that "poor laws" and the exclusion of paupers were police power measures. Id. at 156.

34. Id. at 161. Confirming this account without citation, Marshall's biographer added that Johnson and Duvall had taken the same position, but that the former's absence prevented a decision. 4 A. Beveridge, THe Life of JoHn MARshall 583 (1919).

35. See McGovney, A Supreme Court Fiction: Corporations in the Diverse Citizenship Jurisdiction of the Federal Courts, 56 HARv. L. Rev. 853, $877-78$ (1943).

36. See J. Nowak, R. Rotunda \& J. Young, Handbook on Constitumional Law 247 (1978); 2 C. WARREN, supra note 10, at 27. Chancellor Kent, lowever, agreed with Story. $1 \mathrm{~J}$. KENT, Commentaries on Amerucan law 439 n.b (4th ed. New York 1840) (1st ed. New York 1826). See also R. Newmyer, The SUPReme Court UNDer Marshall, and TaNey 102 (1968), contending, among other things, that Miln "flatly contradicted the Gibbons opinion which gave federal law priority in case of conflict," but not identifying any conflicting federal law.

37. U.S. CoNST. art. I, \& 10, cl. 1 .

38. Briscoe v. Bank of Kentucky, 36 U.S. (11 Pet.) 257 (1837). 
seven years earlier, in Craig v. Missouri, ${ }^{39}$ the Court had divided four to three in striking down certificates issued by Missouri under the bills of credit clause. Story's dissent focused on Marshall's broad interpretation of the clause in that case: "it inust comprehend the emission of any paper inedium by a state government, for the purposes of common circulation." "40 In a sparkling display of scholarship, Story gave numerous examples of early issues of paper that had been denominated "bills of credit" even though they were not legal tender, even though special funds were established for their redemption, even though they were payable to bearer on demand, even though they involved no explicit pledge of government credit, and even though they were acceptable in payment of taxes. ${ }^{41}$ Experience had shown, he argued, that none of these devices sufficed to prevent depreciation in value, the mischief the bills of credit clause was designed to prevent. ${ }^{42}$ Finally, if the state could do through a wholly-owned corporation what it could not do directly, "the prohibition is a dead letter. It is worse than a mockery."43 Marshall, he noted once again, had agreed that the law in Briscoe was unconstitutional.44

Responding for the majority, Justice McLean acknowledged that the bills to which the Framers objected had included those payable on demand, chargeable to a fund, or not made legal tender, and that a state could not issue bills of credit indirectly through a corporation. ${ }^{45}$ However, he concluded, in contrast to Craig, the bank in Briscoe had issued the instrument on its own credit, not on that of the state. Unlike the state itself, the bank could be sued without its consent, and thus all its assets could be seized to satisfy the obligation. ${ }^{46}$ Thompson, concurring again, put the same poimt clearly and concisely:

39. 29 U.S. (4 Pet.) 410 (1830); see Currie, States and Congress, 1801-1835, supra note 1, at $960-64$.

40. Briscoe, 36 U.S. (11 Pet.) at 329 (Story, J., dissenting) (quoting Craig, 29 U.S. (4 Pet.) at 432 (Marshall, C.J.)). In contrast to Craig, the facts in Briscoe did not suggest the possibility that the state had, in effect, issued a promissory note for borrowed money, which all agreed it could do. See Briscoe, 36 U.S. (11 Pet.) at 327-28 (Thompson, J., concurring); id. at 33 I (Story, J., dissenting); Craig, 29 U.S. (4 Pet.) at 431-32 (Marshall, C.J.); id at 443 (Johnson, J., concurring); id. at 455-56 (McLean, J., dissenting).

41. Briscoe, 36 U.S. (11 Pet.) at 333-39.

42. Id at 339.

43. Id. at 348.

44. Id. at 328; see also 4 A. BEVERIDGe, supra note 34, at 583 (without citation).

45. Briscoe, 36 U.S. (11 Pet.) at 312-13, 318, 319.

46. Id. at 321. In this connection it may be significant that the Framers forbade only states and not private bankers from issuing paper money. The state court had said only that Craig was "distinguishable in at least one important and essential particular" without saying what that particular was. Briscoe v. Bank of the Commonwealth, $30 \mathrm{Ky}$. (7 J.J. Marsh.) 349, 349 (1832). 
The two great infirmities which attended the bills of credit which circulated as money, and come within the mischief intended to be guarded against by the constitutional prohibition, were the want of some real and substantial fund being provided for their payment and redemption, and no mode provided for enforcing payment . . . , [as the agent who signed the bills] could not . . . be made personally responsible . . . ; and the State was not suable . . . . [T] [Their credit depended solely upon the faith and voluntary will of the State; and were therefore purely bills of credit. But that is not the situation or character of the bills of the bank in question. There is an ample fund provided for their redemption, and they are issued by a corporation which can be sued, and payment enforced in the courts of justice. ${ }^{47}$

Story answered the majority by arguing that the opporturnty to sue the bank was an illusory safeguard because the state could abolish the bank, reclaim its assets, and leave the holders of bank paper without remedy. ${ }^{48}$ The conclusion that such a course would have been constitutional seems hasty: although the bank could hardly object to anything the state might do with its own property, destruction of the bank's ability to pay might well have impaired its contractual obligation to the bill holder im violation of an adjacent clause of article I, section 10.49 Even so, Story might have responded, the state could not be sued to undo its misdeed; whether the holder could collect his due would depend upon whether any state officer was suable under the uncertain criteria laid down by Marshall in Osborn v. Bank of the United States ${ }^{50}$ and Governor of Georgia v. Madrazo. ${ }^{51}$

47. Briscoe, 36 U.S. (11 Pet.) at 327-28. As in Miln, see supra note 25 , the third edition of the official reports contains a long and boring concurring opinion by Baldwin that did not appear in the original. 36 U.S. (11 Pet.) at 327-28s (3d ed. 1884), originally published in H. BALDWIN, supra note 25, at 113-34, reprinted in $9 \mathrm{~L}$. Ed. 928 (1883 ed.). The only Justice to join both Craig and Briscoe, Baldwin explained that he had disagreed with Marshall's broad definition at the time Craig was decided, but had been too busy and too new on the job to express a separate opinion. 36 U.S. (11 Pet.) at 327-28 (3d ed. 1884). He had goue along in striking down the Missouri paper because, unlike the one in Briscoe, it had been issued on the credit of the state itself and had been made legal tender for certain debts. Id. at 328-28b. In contrast to McLean and Thompson, Baldwin gave no reasons for his apparently paradoxical contention that it was better if the state did not promise to redeem. The Court had already rejected his legal-tender argument in Craig; quite apart from Story's impressive contradictory history in Briscoe, that argument made the bills of credit clause entirely redundant.

48. Briscoe, 36 U.S. (11 Pet.) at 344-45.

49. U.S. Const. art. I, § 10, cl. 1 ("No State shall . . . pass any . . Law impairing the Obligatiou of Contracts . . . "); see Curran v. Arkansas, 56 U.S. (15 How.) 304, 319-20 (1853) (removal of assets from state-owned bank impaired obligations owed to its creditors).

50. 22 U.S. (9 Wheat) 738 (1824).

51. 26 U.S. (1 Pet) 110 (1828); see Currie, Federal Courts, 1801-1835, supra note 1, at 695701; see also Beers v. Arkansas, 61 U.S. (20 How.) 527 (1858) (dictum) (state may withdraw consent to be sued in its own courts on obligations previousiy incurred) (discussed infra at note 83). 
The bills of credit clause is seldom heard of today; its function is now largely supplanted in practice by federal statutes regulating the money supply. ${ }^{52}$ Several commentators have agreed with Story that Briscoe essentially overruled Craig and cut the heart out of the clause, ${ }^{53}$ but I think Briscoe was a hard case in which the opposing opinions deal intelligently with the competing considerations. ${ }^{54}$

\section{Charles River Bridge v. Warren Bridge.}

In 1785 the Massachusetts legislature granted a corporate charter to the proprietors of the Charles River Bridge, authorizing them to construct a bridge between Boston and Charlestown and to collect tolls for a period later extended to seventy years. In 1828 the legislature authorized another company to build a second bridge adjacent to the first, providing that the new bridge would revert to the state and become toll-free after a maximum of six years. The proprietors of the first bridge argued that the act authorizing the second bridge impaired the obligation of their charter in violation of article I, section 10.55 The state court held it did not, and a divided Supreme Court affirmed. ${ }^{56}$

Chief Justice Taney's opinion for the Court-his first in a constitutional case-was brief, lucid, and to the point. Rejecting the natural law notions appearing in such early cases as Calder v. Bull ${ }^{\text {T7 }}$ and Fletcher $v$. Peck, ${ }^{58}$ Taney refreshingly insisted the only question was whether the state had promised "not to establish a free bridge at the place where the Warren bridge is erected." 59 Common law precedents estabhished a rule of strict construction for public grants: "'any ambiguity in the terins of the contract, inust operate against the adventurers, and in

52. See, eg., Veazie Bank v. Fenno, 75 U.S. (8 Wall.) 533 (1869) (upholding a prohibitive federal tax on circulating paper issued by state-chartered banks); $5 \mathrm{C}$. Swisher, supra note 3, at 109. The clause was hardly unentioned in a treatise published as early as 1868. See T. COOLEY, CONSTITUTIONAL LIMITATIONS 15 (1868).

53. See, e.g., 1 J. KENT, supra note 36, at 407 n.a; J. MCCLELLAN, supra note 10, at 257-58; A. Mclaughin, A Constitutional History of the United States 463-64 (1935); $R$. NEWMYER, supra note 36, at 101; F. WEISENBURGER, supra note 10, at 160.

54. The Court reaffirmed Briscoe in Woodruff v. Trapnall, 51 U.S. (10 How.) 190, 205 (1850), and Darrington v. Bank of Alabama, 54 U.S. (13 How.) 12, 16-17 (1852), both written by McLean.

55. Charles River Bridge v. Warren Bridge, 36 U.S. (11 Pet.) 420, 423-28 (1837).

56. Taney reported that the state judges had actually been equally divided and had dismissed the complaint to allow the case to be taken to the Supreme Court. Id. at 538; see Charles River Bridge v. Warren Bridge, 24 Mass. (7 Pick) 344 (1829). For a general discussion of the case, see S. Kutler, Privilege and Creative Destruction: The Charles River Bridge Case (1971); 5 C. SwISHER, supra note 3, at 74-98.

57. 3 U.S. (3 Dall.) 386 (1798); see Currie, Supreme Court, 1789-1801, supra note 1, at 871-75. 889-99.

58. 10 U.S. (6 Cranch) 87 (1810); see Currie, States and Congress, 1801-1835, supra note 1, at

59. Charles River Bridge, 36 U.S. (11 Pet.) at 539-40. 
favor of the public, and the plaintiffs can claim nothing that is not clearly given them by the act." "60 The charter did not say it granted an exclusive right; ${ }^{61}$ legislatures had often authorized roads or railroads adjacent to previously chartered turnpikes without legal cliallenge; 62 and the same considerations of public interest that had led Marshall to hold in Providence Bank v. Billings 63 that a corporate charter did not imply a promise of tax immunity led to the conclusion that the mere right to charge tolls should not imply a promise of exclusivity. ${ }^{64}$

As in the other great cases of this first Taney Term, Story dissented vehemently ${ }^{65}$-joined this time by Thompson, ${ }^{66}$ whose record had been considerably less restrictive of state authority. Omitting any trace of his earher flirtations with natural law, ${ }^{67}$ Story argued with impressive historical support that the law had never required strict construction of public grants that were supported by consideration-as in the case before him, where the proprietors lad promised to keep the bridge in good repair. ${ }^{68}$ As Coke and other authorities had establislied, a charter implied "that the legislature shall not do any act directly to prejudice its own grant, or to destroy its value."69 The Court liad so held in Fletcher $v$. Peck, ${ }^{70}$ where it found that a conveyance of land contamed an implicit promise not to retake the property; in the case at hand construction of the second bridge had put an end to toll-paying traffic and destroyed the value of the franchise as effectively as an express revocation. ${ }^{71}$

Story seems right this time; finding an implied promise by the state not to destroy what it had given seems no larder in Charles River Bridge than im Fletcher itself, and Taney's competing precedent al-

60. Id at 544 (quoting Proprietors of the Stourbridge Canal v. Wheeley, 109 Eng. Rep. 1336, 1337 (K.B. 1831)).

61. Charles River Bridge, 36 U.S. (11 Pet.) at 548-49.

62. Id at 551-52.

63. 29 U.S. (4 Pet.) 514 (1830); see Currie, States and Congress, 180I-1835, supra note 1, at 925.

64. Charles River Bridge, 36 U.S. (11 Pet.) at 546-48.

65. Id at 583 .

66. Id at 650.

67. See Currie, States and Congress, 1801-1835, supra note 1, at 902 . In this connection, it may have been significant for Story that the case came from a state rather than a federal court.

68. Charles River Bridge, 36 U.S. (11 Pet.) at 589-611.

69. Id at 617.

70. 10 U.S. (6 Cranch) 87 (1810), cited in Charles River Bridge, 36 U.S. (11 Pet.) at 617; see Currie, States and Congress, 1801-1835, supra note 1, at 889-99.

71. Charles River Bridge, 36 U.S. (11 Pet.) at 615-16. At common law, Story added, the grant of a franchise to hold a market or fair or to operate a ferry was consistently lield to be implicitly exclusive; bridges were indistinguishable, and Chancellor Kent had so held. Id. at 618-34. 
lowing a state to tax a corporation it had created ${ }^{72}$ was easily distinguishable. As Justice McLean observed in his concurring opinion, ${ }^{73}$ the ordinary tax does not in fact destroy; loose language in McCulloch v. Maryland ${ }^{74}$ notwithstanding, Fletcher showed that even Marshall did not believe the state could destroy its own franchise just because it could tax it. Moreover, in interesting contrast to Marshall's bare assertion in Fletcher that a grant implied a promise not to reassert title, ${ }^{75}$ Story provided an impressive array of common law authorities for his analogous conclusion in Charles River Bridge. ${ }^{76}$ Taney was unable to refute him, alleging only that many owners of railroads and turnpikes had put up with competitors-he did not say with competitors who had charged nothing-without going to court. Unlike his Miln opinion, Story's Charles River dissent seeins both admirable and convincing. ${ }^{77}$

\section{Later Contract Clause Cases}

Contract clause cases dominated the Supreme Court's docket in the Taney period even more than they had during that of Marshall. Despite the discouraging tone of the Charles River Bridge decision, thirty of the over one hundred constitutional decisions between 1837 and 1864 involved contract clause claims. Moreover, Taney and his colleagues enforced the clause vigorously in many cases; it remained

72. Id. at $546-48$ (Tancy, C.J.).

73. Id. at 566-67. McLean agreed with Story that the franchise was exclusive, but he argued there had been no contractual impairment. The state, McLean argued, had taken the bridgeowners' property without compensation, which a Massachusetts court could give them under the state constitution; but the state had not promised it would not exercise the power of eminent domain. McLean added that, but for Fletcher, he would not have thought the contract clause applied to grants at all, but only to executory agreements. Id. at 573 .

The third edition of the reports also contains Baldwim's third consecutive long and boring concurrence, see 36 U.S. (11 Pet.) at 583-83ee (3d ed. 1884), of the same questionable origin as those in Miln and Briscoe. See supra notes 25,47 . Baldwin agreed with Tancy's reasoning and recited prodigious numbers of ancient precedents about ferries in such an unfocused manner as to make Story's more professional use of authority all the more luminous.

74. 17 U.S. (4 Wheat.) 316, 427 (1819); see Currie, States and Congress, 1801-1835, supra note 1 , at $927-38$.

75: Fletcher, 10 U.S. (6 Cranch) at 136-37.

76. See supra text accompanying note 68 .

77. Webster and Kent thought Taney's decision had destroyed the contract clause. See C. SwISHER, supra note 10, at 377-78. Later observers have tended to deny that the case represented a sharp break with Marshall's jurisprudence, pointing to Providence Bank. See, e.g., B. WRIGHT, The Contract C2ause of the Constitution 63-65 (1938).

This time Story did not say Marshall had agreed with him; and while Swisher reported that he had, C. SwISHER, supra note 10, at 363; see also 2 C. WARREN, supra note 10, at 28, one of the lawyers in the case said he had been "credibly informed" to the contrary. See G. DUNNE, supra note 10, at 364 \& n.18 (1970); S. KUTLER, supra note 56, at 172-79; see also G. DUNNE, supra note 10, at 360 (questioning whether Story should have recused himself, in view of his teaching position at Harvard University, which was entitled to a share of the tolls). 
the basis of more decisions striking down state legislation than any other clause of the Constitution. Many of the cases had no doctrinal significance, and merely applied settled principles to yet another fact situation; the important cases can be discussed in rather short compass.

\section{A. Bronson v. Kinzie.}

After Kinzie had mortgaged land to Bronson, the Illinois legislature enacted statutes forbidding foreclosure sales for less than twothirds of market value and giving a mortgagor and his judgment creditors a right to redeem within a year after sale. Over the lone dissent of Justice McLean, the Court held that both laws offended the contract clause. ${ }^{78}$

Decided in 1843, Bronson was the first major contract clause case since Charles River Bridge. Chief Justice Taney again wrote for the majority, and again the opinion displayed an economy and lucidity of style coupled with a tendency to rely on precedent. There, however, the resemblance ended: the earlier opinion had given a niggardly interpretation of a charter, but in Bronson, jomed by five of his Democratic brethren, ${ }^{79}$ Taney dehivered a ringing affirmation of the contract clause.

In Taney's view, the earlier Illinois law giving the mortgagee an unrestricted right to foreclose "entered into the contract, and formed a part of it, without any express stipulation to that effect in the deed." 80 The later statute extending the right of redeinption acted "directly upon the contract itself' by giving the mortgagor and his other creditors "an equitable estate in the premises, which neither of them would have been entitled to under the original contract," and thus inipaired the initial obligation. ${ }^{81}$ That the other provision requiring a sale price at least two-thirds of the land's value "apparently acts upon the remedy"82 did not save it; although the clause often allowed remedial alterations "render[ing] the recovery of debts more tardy and difficult,"

78. Bronson v. Kinzie, 42 U.S. (1 How.) 311 (1843).

79. Thompson, Baldwin, Wayne, Catron, and Daniel joined Taney's opinion. Story and McKinley were absent. Id. at $322 \mathrm{n.*}$. As we shall see, in McKinley's case absences were not at all unusual. Story later expressed warm support for the opinion in a letter to Taney. See 2 C. WARREN, supra note 10 , at 103.

80. Bronson, 42 U.S. (1 How.) at 319; see also id at 321.

81. Id at 319-20. The Court reaffirmed this holding in Howard v. Bugbee, 65 U.S. (24 How.) 461 (1861) (Nelson, J.).

82. Bronson, 42 U.S. (1 How.) at 320.

83. Id. at 315-16. See Crawford v. Branch Bank, 48 U.S. (7 How.) 279, 282 (1849) (McLean, J.), upholding a law retroactively authorizing banks to sue in their own names on notes payable to their officers ("The law is strictly remedial. . . This is nothing more than carrying out the contract according to its original intendenent."), and Beers v. Arkansas, 61 U.S. (20 How.) 527, 530 (1858), allowing a state to require holders to deposit previousiy-issued bonds in court before suing 
Taney endorsed the Marshall Court's condemnation of acts that "so change the nature and extent of existing remedies as materially to impair the rights and imterests of the owner," "84 and commendably refused "to sanction a distinction between the right and the remedy, which would render the provision illusive and nugatory."85 The twothirds law in Bronson crossed this forbidden line because "its effect is to deprive the party of his pre-existing right to foreclose the inortgage by a sale of the premises, and to impose upon him conditions which would frequently render any sale altogether impossible." 86

In Charles River Bridge, 87 Taney had seized on Marshall's refusal to infer corporate tax immunity from a mere state charter as a lever to weaken the protections Marshall had afforded under the contract clause. Notably, Taney did not attempt to do likewise in Bronson; but McLean, in dissent, showed how it could be done.88 Sturges v. Crowninshield 89 had conceded the state's power over renedies; nobody doubted that a state might abolish imprisonment for past debts, though doing so "takes away a means, and often a principal means, of enforc-

on them, in part because the state's requirement "merely regulated the proceedings in its own courts."

84. Bronson, 42 U.S. (1 How.) at 316 (quoting Green v. Biddle, 21 U.S. (8 Wheat.) I (1823)); see Currie, States and Congress, 1801-1835, supra note 1, at 889-927.

85. Bronson, 42 U.S. (1 How.) at 318; see also id. at 317:

[N]o one, we presume, would say that there is any substantial difference between a retrospective law declaring a particular contract or class of contracts to be abrogated and void, and one which took away all remedy to enforce them, or encumbered it with conditions that rendered it useless or impracticable to pursue it.

86. Id at 320. In saying all this, Taney, in best Marshall fashion, had gone further than the case required. As he acknowledged, the mortgage in question expressly authorized a foreelosure sale, so the case could have gone off on Justice Washington's narrower ground that when a contractual provision gave the right to a particular remedy, that remedy was a part of the obligation itself. Id. at 320-21; see Mason v. Haile, 25 U.S. (12 Wheat.) 370, 379 (1827) (dissenting opinion); Currie, States and Congress, 1801-1835, supra note 1, at 912-16.

Bronson was later extended to a contract lacking an express foreclosure provision. McCracken v. Hayward, 43 U.S. (2 How.) 608 (1844). In what appears to be the only constitutional opinion he wrote for the Court in fourteen years, Justice Baldwin repeated inuch of what Bronson had said already, even though, as Catron protested in his concurring opinion, there seemed to be no occasion to reach the constitutioual question. Id. at 617; see also Lessee of Gantly v. Ewing, 44 U.S. (3 How.) 707, 717 (1845) (Catron, J.) (striking down a similar law on the basis of Bronson).

87. Charles River Bridge v. Warren Bridge, 36 U.S. (11 Pet.) 420 (1837).

88. McLean reached the merits reluctantly after arguing that the Ccurt should not have reached the constitutional questions at all. The circuit court rule referring to state law seemed to have been superseded by equity rules later adopted by the Supreme Court; furthermore, the old rule by its own terms made the two-thirds law applicable only to legal and not to equitable proceedings. Bronson, 42 U.S. (1 How.) at 322-23. McLean's charge that the Ccurt was reaching out to make an unnecessary constitutional prenouncement suggested yet another unfortunate parallel between Taney and Marshall; however, it received no reply.

89. 17 U.S. (4 Wheat.) 122 (1819); see Currie, States and Congress, 1801-1835, supra note 1, at $910-16$. 
ing . . payment," or shorten the period of suing on existing contracts, though doing so "bars the right of action." "[S] "S]rely," McLean reasoned, "the exercise of the lesser power, by inodifying the remedy at discretion, must also be constitutional."91 Indeed, though McLean did not say so, Marshall had conceded both of his examples in Sturges; and the Court had actually upheld the state's power to abolish debtors' prison retroactively in Mason $v$. Haile..$^{92}$

McLean's attempt to distinguish the Court's best precedent was lame, ${ }^{93}$ but Marshall had asked for trouble in Sturges by making such broad concessions about the power to alter remedies. Whether the measures endorsed in Sturges were less intrusive than Illinois's twothirds rule, moreover, Taney did not bother to say. 94 Ninety years later his successors would uphold a law authorizing two-year extensions of a redemption period and suspension of the right to a deficiency judgment; 95 even without this glaring contrast, it is difficult to argue that Bronson was hostile to the contract clause. 96

90. Bronson, 42 U.S. (1 How.) at 328 (McLean, J., dissenting).

91. Id; see C. SwishiER, supra note 10, at 387-88 (terming McLean's position "odd . . in view of the conservative ideas on property rights which he was known to hold" and opining that his convictions may have yielded to his "perennial hopes of achieving the presidency").

92. 25 U.S. (12 Wheat) 370 (1827).

93. Green v. Biddle, 21 U.S. (8 Wheat.) I (1823), had struck down squatter laws impairing the rights of landowners although conceding that they went only to the remedy. McLean argued that Green involved an interstate compact and not the Constitution, Bronson, 42 U.S. (1 How.) at 327-28, but the Court had treated the compact as a contract protected against impairment by the contract clause.

McLean's analogy to the right of a court applying foreigu law to employ its own procedures, id. at 329-30, was both intrusive and restrictive; in theory the court was expected not to interfere with vested rights under the guise of procedure. See generally 3 J. BEALE, A TREATISE ON THE CONFLICT OF LAWs \& 584.1 (1935); J. STORY, COMMENTARIES ON THE CONFLICT OF LAWS $\$$ 55658, at 468-70 (Boston 1834).

94. Taney conceded that a state could retroactively exempt tools or household furniture from execution, Bronson, 42 U.S. (1 How.) at 315, but did not say why such measures were less destructive of the right than the two-thirds rule. See B. WRIGHT, supra note 77, at 70 ("This opimion does little more than say that the change in the remedy must, in the opinion of the Court, be a reasonable one.").

95. Home Bldg. \& Loan Ass'n v. Blaisdell, 290 U.S. 398 (1934).

96. See C. SwisHER, supra note 10, at 389 (Bronson "quieted the last of the fears that the court would eventually overthrow the major doctrines of Taney's predecessor"); 2 C. WARREN, supra note 10, at 103 (Bronson "carried Marshall's view of obligation of contract even further than Marshall had himself"); Harris, Chief Justice Taney: Prophet of Reform and Reaction, 10 VAND. L. REv. 227, 238 (1957); see also Curran.v. Arkansas, 56 U.S. (15 How.) 304, 319-20 (1853) (Curtis, J.) (relying on Bronson in holding that the withdrawal of all realty from a state-owned bank impaired its obligations to its creditors by leaving them without reinedy). But see Beers v. Arkansas, 61 U.S. (20 How.) 527, 529-30 (1858) (Tancy, C.J.) (dictum) (Court unanimously said a state would be free to withdraw its consent to be sued on bonds previously issued). 
B. West River Bridge Co. v. Dix.

In 1795 Vermont granted an exclusive one hundred year franchise to build and operate a toll bridge. In 1843 a Vermont county court ordered the bridge taken for public use on payment of $\$ 4000$. In an 1848 opinion by Justice Daniel, ${ }^{97}$ over Justice Wayne's dissent, the Supreme Court held that the taking had not constituted an impairment of the bridge company's contract.98

This result may not seem surprising; not only the state courts cited by Daniel ${ }^{99}$ but even the rigid Justice Story had acknowledged that a state could take bridge franchises, like any other property, on payment of just compensation. ${ }^{100}$ Yet neither Daniel nor Story gave a satisfactory answer to the crucial question earher posed by Justice Johnson in his concurrence to Fletcher $\nu$. Peck:101 how could the exercise of eininent domam be reconciled with the Fletcher holding that the state had implicitly promised not to take back the property it had granted?

Vermont's counsel canie up with a promising response: the grantor had agreed only that it would not impair the grant, and compensation gave the grantee the equivalent of his original right. ${ }^{102}$ There was something to Webster's riposte that compensation was not really the same as the franchise itself; ${ }^{103}$ the owner miglit have preferred not to sell his rights, and the traditional availability of specific performance of land contracts suggests the madequacy of damages in this area. The basis of Fletcher's implied promise, however, was the reasonable expectations of the parties; in these terms a promise not to steal property is much easier to infer than a promise not to buy it at a fair price. In refusing to infer a promise not to tax a corporation, Providence Bank $v$. Billings ${ }^{104}$ had shown that a grant did not imply rights superior to those of others similarly situated; and Charles River Bridge had refused to

97. Daniel had replaced Barbour in 1841. See supra note 2.

98. West River Bridge Co. v. Dix, 47 U.S. (6 How.) 507 (1848).

99. Id. at 534-35.

100. Charles River Bridge v. Warren Bridge, 36 U.S. (11 Pet.) 420, 644 (1837) (dissenting opinion).

101. 10 U.S. (6 Cranch) 87, 143 (1810) (concurring opinion); see Currie, States and Congress, 1801-1835, supro note 1, at 889-99.

102. West River Bridge, 47 U.S. (6 How.) at 525 (Mr. Phelps); see Hale, The Supreme Cours and the Contract Clause: II, 57 HARv. L. REv. 621, 638-39 (1944) (arguing that retaking a granted franchise might "be regarded as a breach" rather than an impairment of the obligation and citing Hays v. Port of Seattle, 251 U.S. 233 (1920), as establishing that the state had the option under the contract clause of breaking its agreement and paying damages).

103. West River Bridge, 47 U.S. (6 How.) at 517 (Messss. Webster \& Collamer).

104. 29 U.S. (4 Pet.) 514 (1830); see Currie, States and Congress, 1801-1835, supra note 1, at 925. 
infer a promise not to undermine the value of a bridge franchise even without compensation. ${ }^{105}$

Justice Daniel, however, invoked neither these precedents nor the cogent arguments of counsel. After describing eminent domain (without citation) as an essential attribute of "every sovereign political community,"1.06 he insisted without further explanation that the franchise implicitly provided for its exercise. ${ }^{107}$ Thus Daniel reached by pure fiat a conclusion he could easily have justified; and, by finding an implicit reservation of the taking power instead of simply declining to find an implied promise not to exercise it, he made the issue look harder than it was. ${ }^{108}$

Moreover, the argument that Fletcher's implicit promise not to destroy a grant does not prevent a compensated taking seemed to require an examination into the adequacy of the compensation. Nevertheless, though the franchisee's counsel had argued that the price paid was grossly insufficient, ${ }^{109}$ Daniel expressly declined to undertake that inquiry. ${ }^{110}$ Indeed he never clearly said, though Fletcher would seem to require it, that compensation had to be paid at all. Thus, although the general principle established in West River Bridge appears both reasonable as a matter of contract interpretation and in accord with precedent, the majority opimion gave the states an easy means of circumventing Fletcher v. Peck without even adverting to that decision.

105. See supra notes 55-77 and accompanying text.

106. West River Bridge, 47 U.S. (6 How.) at 531.

107. Despite a general statement that "all private rights" were held subject to the power of eminent domain, id at 532, Daniel did not say the state could not validly promise to waive the exercise of its power. As he saw the case, the state had not attempted to make such a promise. Thus there seems no basis for the apparent suggestion in B. WRIGHT, supra note 77, at 66-67, that the issue was "the imalienability of the right of eminent domain," for the flat statement in J. NowAK, R. RotundA \& J. YouNG, supra note 36, at 423, that West River Bridge held the power inalienable, or for the conclusion in J. FRANK, supra note 10, at 210-12, that the case established a "police-power limitation on the contract clause." Cf. infra text accompanying notes 130-52 (discussion of contractual tax immunities).

108. Woodbury, who had replaced Story in 1845 , said much the same thing in a concurring opinion, adding unnecessarily that he doubted any necessity could justify taking private property for uses such as marine hospitals and jails. West River Bridge, 47 U.S. (6 How.) at 546. He also said, even less relevantly, that he thought a state could modify at will a contract of employment of a public officer. Id. at 548; see infra notes 111-29 and accompanying text (discussing Butler $v$. Pennsylvania, 51 U.S. (10 How.) 402 (1850)). McLean, as in Charles River Bridge, concurred on the ground that a taking of property was not an impairment of contract. West River Bridge, 47 U.S. (6 How.) at 536-39. Justice Wayne was reported to have "delivered a dissenting opinion," but its contents were not revealed. Id. at 549 .

109. West River Bridge, 47 U.S. (6 How.) at 513, 520 (placing the value of the franchise at s10.000).

110. Id. at 535. 
C. Butler v. Pennsylvania.

Less than a year after appointing Butler a canal commissioner "for the term of one year" with "all the rights, powers, and einoluments of the said office" under a statute providing a compensation of four dollars per day, the state of Pennsylvania reduced his salary and then replaced him entirely. ${ }^{111}$ The state courts rejected the argument that this conduct had impaired the contractual obligation. ${ }^{112}$ In 1851 the Supreme Court affirmed, without dissent on the inerits, in another opinion by Justice Daniel. ${ }^{113}$

Pennsylvania case law, which Daniel cited, ${ }^{114}$ emphatically denied that public officers enjoyed a contractual relation with the state, and ever since Ogden $v$. Saunders ${ }^{115}$ the Court had proceeded on the premise that the existence and extent of an obligation depended on the law in effect at the time the obligation allegedly arose. Thus, having checked that the Pennsylvania decisions were not latter-day concoctions to evade the contract clause, 116 the Court could easily have justified its decision on the ground that the governing state law created no obhigation.

Daniel took a broader approach, however, concluding that appoimtments of state.officers "do not come within the import of the term contracts" in the Constitution. ${ }^{117}$ The contract clause, he said (again without citation), applied only to "contracts by which perfect rights, certain definite, fuxed private rights of property, are vested"; 118 "froin the necessity of the case, and according to universal understanding," engagements "undertaken by the body politic or State government for the benefit of all" could be varied at will. ${ }^{119}$ A contrary holding would be "reconcilable with neither common justice nor common sense"; it would either "arrest necessarily every thing like progress or improve-

111. Butler v. Pennsylvania, 51 U.S. (10 How.) 402, 403-05 (1850).

112. Id. at $405-06$.

113. Justice McLean argued that there was no contract to be impaired and thus no jurisdiction; the logic of this position suggests that the Court never has jurisdiction to reject a constitutional claim on the merits. Id. at 419 .

114. Id. at 517-18.

115. 25 U.S. (12 Wheat.) 213 (1827); see Currie, States and Congress, 1801-1835, supra note 1, at $917-23$.

116. Cf. Indiana ex rel. Anderson v. Brand, 303 U.S. 95, 100 (1938) (whether the statc has bound itself by contract is a question "primarily of state law" which the Court should review only with deference "in order that the constitutional mandate may not become a dead letter"); infra notes 136-52 and accompanying text (discussing Piqua Branch of State Bank v. Knoop, 57 U.S. (16 How.) 369 (1854)).

117. Butler, 51 U.S. (10 How.) at 417.

118. Id. at 416.

119. Id 
ment in government" or turn the state into "one great pension establishment on which to quarter a host of sinecures." 120 The regulation and appointment of state officers, he added, were "functions . . . which governments cannot be presumed to have surrendered, if indccd they can under any circumstances be justified in surrendering them."121

There is in these passages a strong echo of Marshall's habit of concluding that the Framers have done no wrong. ${ }^{122}$ There is the bare assertion that foisting "sinecures" on the public payroll is worse than breaking faith with one's employees. ${ }^{123}$ There is the unsupported attribution of this same set of values to those who wrote into the Constitution an explicit requirement that the states keep their promises. There is no attempt to reconcile the broad conclusion that the contract clause is inapplicable to engagements "for the benefit of all" with the Dartmouth College case, which had held that a charter granted to an eleemosynary imstitution for the public good was protected by the Constitution, ${ }^{124}$ or to explain why the canal commissioners in Butler had rights any less "perfect," "definite," "fixed," "vested," or "private" than those of Dartmouth itself.

The Court could have made a respectable effort along this line. Marshall had conceded in Dartmouth that the contract clause did not "restrain the states in the regulation of their civil institutions, adopted for internal government,"12s and even Story had acknowledged that states could abolisl municipal corporations. ${ }^{126}$ On the other hand, as Justice Washington had explained, in the case of a inunicipal corporation the state was essentially contracting with itself. ${ }^{127}$ Butler, in con-

120. Id

121. Id at 417 . These last passages confused the basis of the holding by suggesting two grounds distinct from the question of what constituted a "contract" within the meaning of the clause. Daniel's statement that the state's surrender of power to alter an officer's salary "cannot be presumed" seemed to suggest a narrow interpretation of the agreement itself, id; his doubt whether the state could make such a surrender seemed to echo the undeveloped suggestion of both Marshall and Johnson in Fletcher v. Peck, 10 U.S. (6 Cranch) 87 (1810), that the state constitution might limit the authority of the state government to contract away its sovereign powers. $C f$. infra notes 130-52 and accompanying text (discussing contractual tax exemptions).

122. See Merrill, Application of the Obligation of Contract Clause to State Promises, $80 \mathrm{U}$. PA. L. REv. 639, 656 (1932) (arguing that the "considerations of policy set forth in [Butler] . . . seem unanswerable"). See generally Currie, Federal Courts, 1801-1835, supra note 1; Currie, States and Congress, 1801-1835, supra note 1.

123. Butler, 51 U.S. (10 How.) at 416.

124. Trustees of Dartmouth College v. Woodward, 17 U.S. (4 Wheat.) 518 (1819); see Currie, States and Congress, 1801-1835, supra note 1, at 905-10.

125. Dartmouth, 17 U.S. (4 Wheat.) at 629.

126. Id. at 694 (concurring opinion); see also Terrett v. Taylor, 13 U.S. (9 Cranch) 43, 52 (1815); Currie, States and Congress, 1801-1835, supra note 1, at 901-05.

127. Darmouth, 17 U.S. (4 Wheat.) at 661 (coneurring opinion). 
trast, also involved the interests of the officers themselves, and Story had admitted that an agreement to pay an officer a stipulated salary would fall within the contract clause. 128

In short, as in West River Bridge, Daniel could have written a persuasive opinion to justify his decision sustaining state authority; but, as in West River Bridge, he elected to rely on bare assertions instead. 129

\section{The Tax Exemption Cases.}

With the conspicuous exception of Bronson v. Kinzie, ${ }^{130}$ all the opinions discussed so far display a marked hostility to the contract clause; and only Bronson involved a contract between private parties. The tempting inference that the Taney Court distinguished sharply between public and private contracts, however, is severely weakened by that Court's sympathetic approach to state promises not to inpose taxes.

The Marshall Court had enforced a state promise not to impose taxes as early as 1812 in New Jersey v. Wilson. ${ }^{131}$ In 1845, in Gordon $v$. Appeal Tax Court, ${ }^{132}$ the Taney Court unanimously enforced another, construing a promise not to impose additional taxes on banks to forbid taxation of their shareholders. ${ }^{133}$ Though perhaps correct, ${ }^{134}$ this inter-

128. Id at 694. Story had left the Court before the Butler decision, and no Justice picked up his argument. Daniel's apparent view that no agreements of public employment were within the contract clause has not survived. See, e.g., Indiana ex rel. Anderson v. Brand, 303 U.S. 95, 99-100 (1938); Hale, supra note 102, at 666-70.

129. Justice Woodbury's opinion the same term for a unanimous Court in Town of East Hartford v. Hartford Bridge Co., 51 U.S. (10 How.) 511 (1850), provides an interesting contrast to Butler. Woodbury invoked both Washington's and Story's Dartmouth opinions to reach the less controversial conclusiou that the state could rescind a ferry right it had granted to a municipal corporation. Id. at 536. However, the broad holding of East Hartford that arrangements between states and their subdivisions lay outside the contract clause was unnecessary in light of the altemative conclusion of estoppel: the city had earlier admitted it held the ferry at legislative pleasure. Id. at 537. Woodbury also added both that the legislature had no power to surrender the right to retract its franchises, id at 534-35, and that it had implicitly reserved power to modify the arrangement as public need dictated. Id. at 536-37. Both these points seemed equally applicable to grants to private parties, and in that context they appeared to conflict with all the precedents refusing to allow alteration of public grants; but they were both quite unnecessary to the decision.

130. 42 U.S. (1 How.) 311 (1843); see supra text accompanying notes 78-96.

131. 11 U.S. (7 Cranch) 164 (1812); see Currie, Stares and Congress, 1801-1835, supra uote 1, at $899-900$.

132. 44 U.S. (3 How.) 133 (1845).

133. The promise was found in a statute providing that if existing banks would invest in a proposed turnpike and pay an annual sum of twenty cents per liundred dollars of capital stock, "the faith of the state is liereby pledged not to impose any further tax or burden upon them during the continuation of their charters under this act." See id at 146.

134. Counsel had argued that the exemption would otherwise become worthless. Gordon, 44 U.S. (3 How.) at 139. Wayne said the condition that the exemption take effect on acceptance by "the bank" showed the legislature had equated the institution with its owners, since they alone 
pretation was hardly compelled by clear language; the decision seemed to show that, despite Charles River Bridge, the Taney Court would not always take a restrictive view of promises in public contracts. ${ }^{135}$ The major 1854 case of Piqua Branch of State Bank v. Knoop ${ }^{136}$ demonstrated that the Gordon decision was no mere sport. ${ }^{137}$ Ohio had passed a statute authorizing any group of five or more persons to form a banking corporation, requiring any bank so organized to pay the state six percent of its net profits semiannually, and providing that this amount "shall be in lieu of all taxes to which such company, or the stockholders thereof on account of stock owned therein, would otherwise be subject." 138 The Ohio courts upheld a later statute taxing the capital stock, surplus, and contingent fund of such banks. The Supreme Court, in an opinion by McLean, reversed.

As Campbell poimted out in a well-written and well-documented dissent joined by Catron and Daniel, ${ }^{139}$ the state had not explicitly promised that the taxing arrangement in the 1845 statute would reinain unaltered by subsequent legislation. ${ }^{140}$ In contrast to the pledge in Gordon to inipose no further tax on banks "during the contimuance of their charters," the assurance in Piqua, by which the state had only declared that the semiannual payments should be "in lieu of all taxes,"

could agree to the terms of the bargain. Id at 147-48. Professor Wright termed Wayne's conclusion "very doubtrul." B. WRIGHT, supra note 77, at 183.

135. Indeed, Wayne rejected an argument that the exemption applied only to franchise taxes on the ground that the banking franchise itself, unlike land acquired from the state, would lave been implicitly exempt in the absence of an express provision: the bank paid a price for the privilege, "and any tax upon it would substantially be an addition to the price." Gordon, 44 U.S. (3 How.) at 146. Despite Wayne's disclaimer, this argument would appear equally applicable to every sale of state land, or for that matter to every corporate charter for which there is consideration (though Wayne explicitly denied this application, id at 145-46). This incidental conclusion that bank franchises possessed implicit immunity from taxes seemed not only out of harmony with the principles of construction set forth and applied in Charles River Bridge, but also irreconcilable with Marshall's holding in Providence Bank v. Billings that the mere grant of a charter did not imply an exemption from state taxes. Providence Bank, 29 U.S. (4 Pet.) at 560-65; see Currie, Stares and Congress, 1801-1835, supra note 1, at 925; see also supra text accompanying note 63.

136. 57 U.S. (16 How.) 369 (1854). For the background and aftermath of this controversy, see 2 C. HAINES \& F. SHERWOOD, supra note 25, at 370-89; 2 C. WARREN, supra note 10, at 474-81.

137. In 1842 the Court had held that a statute making the property of a state university "forever" tax free was implicitly repealed by a later law authorizing sale to private parties. Armstrong v. Treasurer of Athens County, 41 U.S. (16 Pet) 281 (1842) (Catron, J.). Unlike the otherwise similar exemption in New Jersey y. Wilson, 11 U.S. (7 Cranch) at 166-67, the exemption in Armstrong had not been a part of the consideration for a private grant protected by the clause. $C f$. Philadelphia \& Wilmington R.R. v. Maryland, 51 U.S. (10 How.) 376, $382-83$ (1850) (Taney, C.J.) (statute authorizing merger and continuing "all . . . privileges" of predecessor corporations did not extend tax immunity of one predecessor to all the property of the new firm).

138. Piqua, 57 U.S. (16 How.) at 377.

139. Id. at 395,405 .

ien Id. at 406. 
might as easily mean "till otherwise provided by law" " as "during the existence of the banks" "; ${ }^{141}$ as Campbell said, Charles River Bridge seemed to require a resolution of the ambiguity in favor of the state. ${ }^{142}$

In a separate dissent, Catron added a more fundamental objection: the Ohio courts had already held that irrepealable tax exemptions were an impermissible abandonment of sovereignty, ${ }^{143}$ and the state courts were the ultimate arbiters of state law. ${ }^{144}$ Conceding that federal courts normally deferred to state courts in the interpretation of state law, McLean persuasively responded that the contract clause demanded an exception: to make the state sole judge of whether it had given what the Constitution forbade it to revoke would "surrender one of the most important provisions in the federal Constitution."145

On the merits, McLean noted that state legislatures and prior decisions had long assumed the power to grant irrepealable exemptions ${ }^{146}$ and argued that an agreement not to tax a particular corporation no more abrogated sovereignty than would an agreement to repay money borrowed or the issuance of a corporate charter itself. ${ }^{147}$

141. Gordon, 44 U.S. (3 How.) at 145; Pigua, 57 U.S. (16 How.) at 406.

142. Piqua, 57 U.S. (16 How.) at 409-12. Taney concurred specially to say he did not agree with everything in the majority opiniou but that "the words used are too plain" to avoid McLean's conclusion. Id. at 392-93. The companion case of Ohio Life Ins. \& Trust Co. v. Debolt, 57 U.S. (16 How.) 416 (1854), involved the same statutes, but with a differeut twist and a different result. The company was not, strictly speaking, a bank, but its charter provided it should be taxed no more heavily than banks. Taney and Grier thought the state had agreed to give the company "the ,benefit of its general regulations and laws . . but not of its special contracts" concerning bank taxes, id. at 441 , and the 1845 provision involved in Piqua was a "special contract" applicatie only to banks established under its other provisions. Id at 439. As McLean and Curtis pointed out in separate dissents, id. at 444, 450, this seemed a peculiar construction because every bank in the state was subject to the 1845 rate at the time the statute was passed. Once the Court had answered the liard question in Piqua by favoring exemption, the same result should apparently have followed easily in Debolt, but with the votes of Catron, Daniel, and Canipbell (who adhered to their position that the banks themselves were taxable at the 1851 rate), the vote in Debolt was five to four against immunity. For further discussion of Debolt, sec infra note 147.

143. Pigua, 57 U.S. (16 How.) at 404 (dissenting opinion).

144. Id. at 403,405 .

145. Id at 391-92 (majority opinion); accord Indiana ex rel. Anderson v. Brand, 303 U.S. 95 (1938); cf. Martin v. Hunter's Lessee, 14 U.S. (1 Wheat.) 304, 357 (1816) (investigating whether title had passed under state law before a treaty allegedly violated by expropriation); Currie, Fed. eral Courts, 1801-1835, supra note 1, at 681-87 (discussing Martin v. Hunter's Lessee).

146. Piqua, 57 U.S. (16 How.) at 389.

147. Id. In the companion Debolt case, discussed supra at note 142, Justice Daniel joined Catron's rejection of what Daniel tèrned the "suicidal doctrine" that a legislature could "bind forrever and irrevocably their creator," the "sovereign people." Debolt, 57 U.S. (16 How.) at 443 (Daniel, J., concurring in judgment). Whether this view was cousistent with any legislative power to contract he did not say. Taney, joined by Grier, wrote separately to affirm both the power of Ohio's legislature to give irrepealable exemptions and the Court's duty to reexamine the state's interpretation of its original action, while finding no contractual exeinption on the facts. Id. at 
Absent some unusual provision in the Ohio constitution-and nobody pointed to one-Mclean seemed to have the better of this argument. ${ }^{148}$ Catron's view would reappear in dissents even on the tax issue, ${ }^{149}$ and the Court would later adopt it with respect to alleged promises not to exercise the pohice ${ }^{150}$ and eminent domain ${ }^{151}$ powers. During Taney's term, however, the Court not only enforced tax exemptions; it also gave them, on the whole, a reasonably broad construction $^{152}$ despite the contrary philosophy of Charles River Bridge.

\section{E. Gelpcke v. Dubuque.}

Pursuant to statutory authorization, the City of Dubuque issued bonds in exchange for shares of railroad stock. The Iowa Supreme Court had held before the bond issue that the authorizing statute was consistent with the state constitution; after the issue, the court reversed itself. In a federal diversity action to recover interest, the Supreme Court disregarded the latest state court decision and held for the bondholders. ${ }^{153}$

For the Court, Justice Swayne argued that the "settled rule" requiring respect for state court decisions "giving constructions to the laws and constitutions of their own States" 154 had been held inapphicable in "exceptional cases," 155 none of which he had the grace to identify. The earher Iowa decisions favoring the bonds were "sustained by reason and authority" and "in harmony with the adjudications of sixteen States," and, Swayne noted, "[i]t cannot be expected that this court will follow every . . . oscillation" in state decisions. ${ }^{156}$ As Taney had said in earlier dicta, a contract valid according to contemporaneous state interpretation "cannot be impaired by any subsequent action of legislation, or decision of its courts altering the construction of the

$427,432-33,441$. Campbell once again properly found it unnecessary to decide the broader question. Id at $443-44$ (separate opinion).

148. See also Hale, supra note 102 , at 654.

149. See, eg., Washington Univ. v. Rouse, 75 U.S. (8 Wall.) 439, 443 (1869) (Miller, J., dissenting); B. WRIGHT, supre note 77, at 75.

150. See, eg., Stone v. Mississippi, 101 U.S. 814 (1880).

151. See, e.g., Contributors to Pennsylvania Hospital v. Philadelphia, 245 U.S. 20 (1917).

152. See Jefferson Branch Bank v. Skelly, 66 U.S. (I Black) 436 (1862); Rector of Christ Church v. County of Philadelphia, 65 U.S. (24 How.) 300 (1861); Dodge v. Woolsey, 59 U.S. (18 How.) 331 (1856).

153. Gelpcke v. Dubuque, 68 U.S. (1 Wall) 175 (1864). See generally 6 C. FaIRMAN, HisTORY OF THE-SUPREME COURT OF THE UNITED STATES $935-44$ (1971); C. FAIRMAN, MR. JUSTICE Miller and the SUPreme Court 213-21 (1939).

154. Gelpcke, 68 U.S. (1 Wall.) at 206.

155. Id.

156. Id at 205-06. 
law."157 "To hold otherwise," Swayne added, "would be as unjust as to hold that rights acquired under a statute may be lost by its repeal."158

Whatever else may be said about Gelpcke, Swayne can hardly be accused of having revealed the basis of his decision. ${ }^{159}$ Professor Swisher has taken the Taney quotation as proof the case held that the contract clause precluded judicial as well as legislative impairment of agreements. ${ }^{160}$ Swisher's interpretation is strengthened by the fact that Taney's remark was made in a case decided on contract clause grounds and by a later Swayne statement that, while still ambiguous, was somewhat more explicit. ${ }^{61}$ This interpretation suffers, however, from the conspicuous failure of Swayne ever to mention the contract clause and from Justice Miller's emphatic and uncontradicted assertion in dissent that it was "not pretended" that the Iowa decision was "in conflict with the Constitution of the United States."162 Indeed, the references to "exceptional cases," to "oscillation," and to the correctness of the repudiated Iowa holdings suggest the Court simply thought itself free to depart from a state court's interpretation of its own constitution. This conclusion, although not easy to reconcile with the many precedents cited by Miller ${ }^{163}$ or with the underlying Rules of Decision Act, ${ }^{164}$ indicates Gelpcke may well have been an extension of Swift v. Tyson ${ }^{165}$ rather than an expansive reading of the contract clause.

157. Id. at 206 (citing Ohio Life Ins. \& Trust Co. v. Debolt, 57 U.S. (16 How.) 416, 432 (1854) (separate opinion) (discussed supra notes 142, 147)). Taney was ill when Gelpcke was decided and did not sit. See 68 U.S. (1 Wall.) at vii.

158. Gelpcke, 68 U.S. (1 Wall.) at 206.

159. See B. WRJGH, supra note 77 , at 81 (the "coustitutional justification for the [decision] ... has never been entirely clear").

160. 5 C. SWISHER, supra note 3 , at 335.

161. "The National Constitution forbids the States to pass laws impairing the obligation of contracts. In cases properly brought before us that end can be accomplished unwarrantably no more by judicial decisions than by legislation." Township of Pine Grove v. Talcott, 86 U.S. (19 Wall.) 666, 678 (1874) (discussed infra notes 165, 169), effectively overruled, Eric R.R. v. Tompkins, 304 U.S. 64, 79-80 (1938); see also Douglass v. County of Pike, 101 U.S. 677, 687 (1879) (Waite, C.J.).

162. Gelpcke, 68 U.S. (1 Wall.) at 209; see also id. at 210.

163. Id at 210-13.

164. Act of Sepi. 24,1789 , ch. $20, \S 34$, I Stat. 73,92 (codified as amended at 28 U.S.C. $\& 1652$ (1976)).

165. 41 U.S. (16 Pet.) 1, 18-19 (1842) (Ruies of Decision Act limited to "laws strictly local"), overruled, Eric R.R. v. Tompkins, 304 U.S. 64, 79-80 (1938) (state laws rules of decision in federal courts). The Swiff doctrine was an explicit ground of decision in the Pine Grove case. Pine Grove, 86 U.S. (19 Wall.) at 678 (see supra note 161 for quotation); see also Tidal Oil Co. v. Flanagan, 263 U.S. 444, $451-52$ (1924); 6 C. FAIRMAN, supra note 153, at 937-38 (insisting that Swift was the sole basis for Gelpcke). For a defense of Gelpcke on this ground because of the diversity policy of protecting outsiders from state-court bias, see Thayer, The Case of Gelpcke v. Dubuque, 4 HARV. L. REv. 311 (1891). 
If Swayne did mean to hold that the Constitution forbade judicial impairment of contract, he had some explaining to do. The contract clause forbids only "Law[s]" impairing obligations; 166 the Court had held in Calder v. Bull that the similarly worded ex post facto clause ${ }^{167}$ applied only to legislation. ${ }^{168}$ Swayne might have invoked the purpose of the contract clause to protect legitimate expectations, along with a recognition that judges effectively make law by deciding cases. ${ }^{169}$ Perhaps his failure to do any of this resulted from an imability to muster a majority for what at the time may have seemed an unwarranted extension; it may be rough justice, if hardly consolation, that the Court gave no better explanation when it later said the clause did not apply to judicial decisions. ${ }^{170}$ In any event, though Gelpcke neither clearly expanded the contract clause nor contained any acceptable justification for its holding, it was certainly not unfriendly to contract rights.

\section{F. Summary.}

The cases considered above inake it impossible to conclude that the Court consistently displayed toward the clanse the kind of hostility that its crippling construction of the charter in Charles River Bridge appeared to represent. Bronson v. Kinzie showed that the new Justices had little imclination to nse Marshall's right/remedy distinction to

166. "No State shall . . . pass any . . Law impairing the Obligation of Contracts . . . " U:S. CoNST. art. I, \& 10, cl. 1.

167. "No State shall . . pass any . . ex post facto Law . . . . Id

168. 3 U.S. ( 3 Dall) 386, 392 (Chase, J.), 397 (Patterson, J.), 400 (Iredell \& Cushing, JJ.) (1798) (alternative holding); see Currie, Supreme Court, 1789-1801, supra note 1, at 870-71.

169. In other contexts the Court has since construed the term "laws" to include judge-made law. See Erie R.R., 304 U.S. at 78 (state laws rules of decision in federal courts); Illinois v. City of Milwaukee, 406 U.S. 91,100 (1972) (jurisdiction of cases arising under federal law).

Swayne might also have added that Calder's contrary reading of the ex post facto clause had been assumed rather than explained, and that a limitation on the power to overrule prior contract decisions could more easily be attributed to the Framers than could a prohibition on appeals from inferior courts, which was all that had been involved in Calder. Swayne's later suggestion that to follow state decisions in cases like Gelpcke would be to "abdicate one of the inost important duties with which this tribunal is charged," Pine Grove, 86 U.S. (19 Wall) at 678, echoes McLean's correct conclusion in Piqua that to give binding effect to state decisions when legislation is attacked would emasculate the contract clause. In Gelpcke, however, no legislation was under attack; the issue was the threshold question of whether judicial action could ever offend the clause. Because the case providing Taney's dictum involved an attack on state legislation, and since $\mathrm{Ta}$ ney in the same breath reaffirmed the point made in Piqua, Miller seems correct in saying that Taney had not meant what Swayne appeared to cite him for in Gelpcke. See Gelpcke, 68 U.S. (1 Wall.) at 216-17.

170. See New Oricans Waterworks Co. v. Louisiana Sugar Ref. Co., 125 U.S. 18, 30 (1888) ("The prohibition is aimed at the legislative power of the State, and not at the decisions of its courts, or the acts of administrative or executive boards or officers...."). Because the action involved was not that of a court, the reference to decisions was dictum. 
weaken the clause, and the tax exemption cases demonstrate they were sometimes even generous in their interpretation of government promises. After Marshall's refusal to infer a promise not to tax, there was nothing radical about his successors' refusal in West River Bridge to infer a promise not to exercise the ordinary power of condemnation. Even the relatively extreme holding in Butler that contracts for the employment of state officers were not protected had roots in Marshall's dictum exempting purely governmental arrangements and could easily have been justified on the basis of state law. Though the additional decisions not discussed here may confirm a certain inclination toward narrow construction of public promises outside the tax exemption field, they do not seem to alter the picture very significantly. ${ }^{171}$ In short, notwithstanding Charles River Bridge and occasional extreme statements by unrepresentative Justices like Daniel and Catron, the overall impression conveyed by the contract cases of the Taney years is one of continuity with the Marshall tradition. ${ }^{172}$

171. See, e.g., Bridge Proprietors v. Hoboken Land \& Improvement Co., 68 U.S. (1 Wall.) 116 (1864) (Miller, J.) (imaginative opimion that exciusive bridge franchise did not preclude construction of railroad bridge that was said not to divert tollpaying foot and horse traffic); Gilman v. City of Sheboygan, 67 U.S. (2 Black) 510 (1863) (Swayne, J.) (authorization to impose certain taxes was not part of city's contract with its bondholders); Sherman v. Smith, 66 U.S. (I Black) 587 (1862) (Nelson, J.) (charter provision revocable because state had expressly reserved power of repeal, as Story had said in Dartmouth); Aspinwall v. Board of Commissioners, 63 U.S. (22 How.) 364 (1860) (Nelson, J.) (railroad charter provision authorizing county to buy railroad stock gave county no right protected by contract clause); Richmond, Fredericksburg, \& Potomac R.R. v. Louisa R.R., 54 U.S. (13 How.) 71 (1852) (Gtier, J.) (promise in one railroad franchise not to grant another diverting traffic between terminal points not impaired by chartering another railway over part of same distance); Baltimore \& Susquehanna R.R. v. Nesbit, 51 U.S. (10 How.) 395 (1850) (Damiel, J.) (legislative new-trial order respecting particular condemnation did not impair contractual power of eminent domain); Paup v. Drew, 51 U.S. (10 How.) 218 (1850) (alternative holding) (McLean, J.) (promise to accept banknotes for state debts inapplicable to purchase of land the state held in trust); Phaien v. Virginia, 49 U.S. (8 How.) 163 (1850) (Grier, J.) (state may ban lottery five years after enacting statute authorizing turnpike commissioners to operate one in order to raise $\$ 30,000$ to repair a sinall stretch of road); Woodruff v. Trapnall, 51 U.S. (10 How.) 190 (1850) (McLean, J.) (bank charter promising acceptance of banknotes in satisfaction of debts to the state created a contractual obligation to noteholders); Planters' Bank v. Sharp, 47 U.S. (6 How.) 301, 306 (1848) (Woodbury, J.) (charters empowering banks either to dispose of property or to exercise the "usual . . . powers" of banking institutions gave thein a contractual right to transfer promissory notes); Maryland v. Baltimore \& O.R.R., 44 U.S. (3 How.) 534 (1845) (Taney, C.J.) (charter provision requiring railroad to pay penalty to county if it did not build there gave no contractual right to the county). Many of these decisions were unanimous; but Catron, Daniel, Taney, Nelson, and Grier each dissented from at least one case striking down state action, and McLean, Wayne, and Curtis dissented from the upholding of state action in the Richmond case, Richmond, F., \& P.R.R., 54 U.S. (13 How.) at 83.

172. See B. WRIOHT, supra note 77, at $62-63,245-46$ (concluding that the contract clause was a "more secure and a broader base for the defense of property rights in 1864 than it had been in 1835"). 


\section{Later Commerce Clause Cases}

A. Groves v. Slaughter.

In 1835 and 1836, Slaughter brought slaves into Mississippi and sold thein on credit. ${ }^{173}$ Solne of his customers failed to pay and defended themselves on grounds of illegality: the Mississippi constitution provided that the "introduction of slaves into this state, as inerchandise, or for sale, shall be prohibited, from and after the first day of May, [1833]."174 The trial court rejected this defense, and the Supreine Court, over two dissents, affirmed. ${ }^{175}$

Justice Thompson's opinion for the Court scrupulously avoided the ticklish question whether the commerce clause deprived Mississippi of power to prohibit the importation of slaves, concluding, in the absence of clear state decisions, that its slave importation clause was a mere direction to the legislature, not a self-executing prohibition. ${ }^{176}$ McLean, Taney, and Baldwin each published concurring opinions expressing highly divergent views on the commerce clause issue, which all three conceded did not have to be decided. ${ }^{177}$ Like Story in Miln, McLean began by inflating Gibbons into a holding that Congress had exclusive power over commerce but concluded that slaves were not articles of commerce ${ }^{178}$ because the Constitution referred to them as "persons." 179 Responding persuasively that the clause of article I, section 9 forbidding Congress to outlaw the slave trade before 1808 .

173. Groves v. Slaughter, 40 U.S. (15 Pet.) 449, 497 (1841).

174. Id See geñerally 5 C. SwisHER, supra note 3, at 366 ('the importation of slaves depressed the market value of those already held in the state" and the slave traders brought in slaves who were "troublemakers or in other respects undesirable"); 2 C. WARREN, supra note 10, at 68 n.l (this was "a financial rather than a slavery measure," designed "to check the drain of capital away froin the state").

175. Groves v. Slaughter, 40 U.S. (15 Pet.) 449 (1841).

176. Id at 496-503. Surprisingly, the Court adhered to this conclusion after the Mississippi courts decided to the contrary. See Rowan v. Runnels, 46 U.S. (5 How.) 134, 139 (1847) (Taney, C.J.) (arguing that to give state-court decisions retroactive effect might render the diversity clause "utterly useless and nugatory"). For cogent criticisin of the Rowan decision as inconsistent with precedent, see 2C. HANNES \& F. SHERwOOD, supra note 25, at 120-21 (invoking Green v. Lessee of Neal, 31 U.S. (6 Pet.) 291 (1832)).

177. Groves, 40 U.S. (15 Pet.) at 504 (McLean, J.), 508 (Tancy, C.J.), 510 (Baldwin, J.). McLean began by saying the question was "so intimately comected with" the case and had been "so elaborately argued" that it was "fit and proper" to discuss it. Id at 504. Taney and Baldwin said that, once McLean had spoken, they dared not let their silence be misconstrued. Id at 508 (Taney, C.J.), 510 (Baldwin, J.); see F. WeIsENBUROER, supra note 10, at 165-66 ("Mclean went far out of the usual judicial course" and "neediessly exposed . . . differences . . . on questions of crucial importance.").

178. Groves, 40 U.S. (15 Pet.) at 504, 506-08.

179. Id at 506 (citing U.S. ConsT. art. I, 82 (apportionment of representatives and direct taxes); U.S. Const. art. I, 89 (congressional power over slave trade); U.S. CoNST. ant. IV, \& 3 (fugitive slaves)); see C. SwISHER, supra note 10, at 398 (explaining that despite his nationalist 
demonstrated that slaves otherwise fell within the commerce power, ${ }^{180}$ Baldwin admitted that a law forbidding the importation of all slaves could have been sustained under the police power on grounds either of morality or safety, but argued convincingly that the purpose of the Mississippi provision was purely commercial because it forbade only importation for sale. ${ }^{181}$ Taney said only that the introduction of slaves was a state matter not subject to congressional control; he did not say why. ${ }^{182}$

Between the opinions of Taney and Baldwin, the reporter added the following peculiar paragraph.

Mr. Justice StoRy, Mr. Justice Thompson, Mr. Justice WAYNe, and Mr. Justice M'KINLEY concurred with the majority of the Court in opinion that the provision of the Constitution of the United States, which gives the regulation of commerce to Congress, did not interfere with the provision of the constitution of the state of Mississippi, which relates to the introduction of slaves as merchandise, or for salc. ${ }^{183}$

For Story and McKinley, who dissented from the decision that Mississippi's constitution was not self-executing, ${ }^{184}$ the quoted paragraph meant the state had power to forbid the importation of slaves for sale. That Thompson and Wayne joined in this paragraph-rather than resting solely on the former's conclusion that the Mississippi provision had no legal effect-suggests that they could not resist adding their two-

("Whig") views McLean was "an abolitionist . . . deeply interested . . . in preserving the power of the state to do away with slavery").

180. Groves, 40 U.S. (15 Pet.) at 513-14. McLean responded unconvincingly, suggesting that Congress's power over interstate commerce was narrower than its identically worded power over forcign trade, id. at 505-06, and that, given the exclusivity of the commerce clause, \$ 9's recognition of state authority over slave importation until 1808 showed that the subject fell outside the commerce clause altogether. $I d$ at 506 . The latter contention overlooked the possibility that such state laws might fall within Marshall's conception of the police power (which McLean conceded gave the states some authority to affect the same subject as Congress' commercial regulations, id. at 505), as well as the Framers' explicit termination of the limitation as of 1808.

181. Groves, 40 U.S. (15 Pet.) at 511-12, 516. This time, Baldwin seems to have captured the spirit of Marshall's distinction. Cf. supra notes 25, 47, 73 (discussing New York v. Miln, Briscoe v. Kentucky, and Charles River Bridge v. Warren Bridge). He was less successful, however, in suggesting a violation of the privileges and immunities clause of article IV, see Groves, 40 U.S. (15 Pet.) at 516-17, because Mississippi appeared to disapprove of importation for sale by its own citizens as well as by outsiders. Unable to stay within the case, Baldwin also added (in anticipation of Scott v. Sandford, 60 U.S. (19 How.) 393 (1857)), that slaveowners were "protected from any violations of rights of property by Congress, under the fifth amendment." Groves, 40 U.S. (i5 Pet.) at 515 .

182. Id. at 508-09. Taney correctly noted that the exclusivity question remained open, but then made the "astonishingly inaccurate prediction," C. SwisHER, supra note 10, at 398, that the Court would never have to decide it. Groves, 40 U.S. (15 Pet.) at 509-I0.

183. Groves, 40 U.S. (15 Pet.) at 510.

184. Id. at 517 . 
cents-worth on the issue Thompson had so carefully and properly avoided. None of the four, however, gave any inkling of a reason for their conclusion. ${ }^{185}$

Inconclusive as it was on the commerce clause issue, Groves did serve to repudiate Webster's astounding assurance during argument that "all questions" relating to the clause "are now fully settled." 186 Six of the seven participating Justices ${ }^{187}$ apparently concluded that Mississippi could forbid the importation of slaves for sale; the seventh seemed to suggest it could have excluded slaves entirely. For all but two of them, however, this was only dicta. The three Justices who gave reasons for their decision took three distinct positions. The other four left us to wonder whether they thought such a law valid because the commerce power was not exclusive, because of the police power theory apphed in Miln, or because the subject lay wholly outside the commerce clause. ${ }^{188}$ For those counting heads in anticipation of the inevitable commerce clause showdown, after Groves four Justices-Johnson, Story, McLean, and Baldwin-had gone on record that Congress had exclusive power, and only Thompson had yet indicated the contrary.

\section{B. License Cases.}

Convicted of selling imported hquor without licenses required by state law, the defendants in three separate cases attacked their convictions on constitutional grounds. The Supreme Court unanimously affirmed, ${ }^{189}$ but it is difficult to say why. There was no opinion for the Court. Of the seven Justices whose vote was reported, six wrote separate opinions; two wrote more than one. ${ }^{190}$

185. McKinley apparently delivered an oral opinion whose contents are unknown; Story was absent when the decision was announced. $5 \mathrm{C}$. SwisHer, supra note 3, at 367.

186. Groves, 40 U.S. ( $15 \mathrm{Pet}$ ) at 494.

187. Catron was absent and Barbour had died. Id. at 517.

188. In a private letter Story said he had concluded that the commerce clause did not oust state power, "admitting it to be exclusive." 5 C. Swisher, supra note 3, at 367 (quoting Letter from Justice Story to Robert J. Walker 2 (May 22, 1841) (available in New York Historical Society Library)). Professor Swisher took this to mean Story thought the state provision to be an exercise of the police power, in contradiction to the broad interpretation of the commerce clause outlined in of his own dissent in Miln. 5 C. Swisher, supra note 3, at 370.

189. License Cases, 46 U.S. (5 How.) 504 (1847).

190. Two of the cases, concerning beverages inuported from foreign countries, principally involved a statutory argument based on Brown v. Maryland, 25 U.S. (12 Wheal.) 419 (1827): federal tariff acts authorized the importation and sale of the goods, and under the supremacy clause the state could not take away what Congress had given. See License Cases, 46 U.S. (5 How.) at 512-14 (Mr. Webster), 546 (Messrs. Ames and Whipple). Taney went out of his way to concede that Brown had been rightly decided, and Daniel did likewise to dispute Taney's view, id. at 575$76,612-16$, but neither case involved a prosecution of the iniporter and nobody seemed willing to extend Brown's peculiar holding beyond the importer himself. 
McLean and Grier ${ }^{191}$ took the easy line: earlier cases confirmed that the commerce clause did not forbid states to protect health and morals under their police powers. ${ }^{192}$ This seemed to be the basis of Marshall's decision in Willson v. Black Bird Creek Marsh Co. ${ }^{193}$ of his quarantine example in Gibbons, and of the nearly unanimous Miln decision; the only Justices who gave reasons in support of the power to exclude slaves in Groves $v$. Slaughter had conceded it. Yet in the License Cases only Woodbury joined McLean and Grier in basing his vote on the police power, ${ }^{194}$ and it was not the sole ground of his opinion. ${ }^{195}$

Woodbury also argued that the sale of imported liquor did not fall within the federal commerce power at all: the interstate transaction ended once the liquor entered the state, and the state had exclusive authority to regulate ensuing sales as a inatter of local commerce. ${ }^{196}$ This seemed a rather extreine position; after $M c$ Culloch $v$. Maryland 197 it could easily have been argued that some federal control over the sale of iniported goods was necessary and proper to prevent the effective obstruction of commerce itself.

Most interesting and inportant was the argument of at least four Justices that Congress' power over commerce was not exclusive. As Taney and Catron convincingly explained, ${ }^{198}$ the Court had never held it was; in contrast to the power to coin money, the Constitution did not say it was, and the Court had held that Congress' comparable powers

There was some discussion in the third case of whether the prohibition on state import taxes, U.S. ConsT. art. I, \$ 10, applied to interstate shipments. See, e.g., License Cases, 46 U.S. (5 How.) at 595 (McLean, J.) (denying application despite contrary dictum in Brown). As Catron said, however, the heense requirement was not even clearly a tax, for it imposed only a nominal fee to cover administrative costs. Id. at 599 . In the cases involving foreign liquor the imports clause argument met the same fate as that based on the tariff act: after leaving the liands of the importer, the hquor was no longer an import. See, e.g., id. at 577 (Tancy, C.J.).

191. Grier had replaced Baldwin in 1846. See supra note 2.

192. License Cases, 46 U.S. (5 How.) at 595, 631-32. Chief Justice Sluaw lad taken this position in upholding the Massachusetts law. Comunonwealth v. Kimball, 41 Mass. (24 Pick.) 359 (1837).

193. 27 U.S. (2 Pet.) 245 (1829); see supra notes 5-6 and accompanying text.

194. License Cases, 46 U.S. (5 How.) at 627-32.

195. Indeed, he appeared to have doubts that the police power conld be nsed to interfere with interstate cominerce itself, although that was what both Groves and the quarantine case seemed to mean. Id. at 630 .

196. Id at 625. Daniel echoed this point. See id at 614-16. Compare this position with the arguments of Taney and McLean in Groves. See supra notes 177-80, 182 and accompanying text.

197. 17 U.S. (4 Wheat.) 316 (1819); see Currie, States and Congress, 1801-1835, supra note 1, at $927-38$.

198. License Cases, 46 U.S. (5 How.) at 578-86 (Taney, C.J.), $601-08$ (Catron, J.). 
over bankruptcy and the militia were not. ${ }^{199}$ Furthermore, quarantine and pilotage laws showed that states had regulated commerce with congressional blessing evcr since 1789, and not because they fell within the "police power"; if federal authority were exclusive, it would be irrelevant whether a state's motive was "to guard the citizens of the State froin pestilence and disease" or to promote "the interests and convenience of trade."200

As usual, Taney's opinion was competent and straightforward.201 Woodbury and Nelson, as well as Catron, agreed with him, ${ }^{202}$ and an aside in Daniel's opinion also seems to suggest the same conclusion. ${ }^{203}$ Only McLean, gratuitously repeating his Groves argument, disagreed. ${ }^{204}$ Grier properly avoided the subject, ${ }^{205}$. McKinley was absent, and Wayne apparently did not vote. ${ }^{206}$ Thus four of the seven Justices who voted declared flatly and persuasively 207 that the commerce clause did not limit state power. It seems unfortunate that Daniel did not express more definitively the similar sentiments he was to utter two years later in a dissent to the Passenger Cases. ${ }^{208}$ Although

199. See Currie, Federal Courts, 1801-1835, supra note 1, at 702-05 (discussing Houston v. Moore, 18 U.S. (5 Wheat.) 1 (1820)); Currie, States and Congress, 1801-1835, supra note 1, at 91016 (discussing Sturges v. Crowninshield, 17 U.S. (4 Wheat) 122 (1819)). Taney persuasively explained that the arguably contrary naturalization decision of Chirac v. Lessee of Chirac, 15 U.S. (2 Wheat.) 259 (1817), was based upon a conflict with federal law. License Cases, 46 U.S. (5 How.) at 585.

200. License Cases, 46 U.S. (5 How.) at 583. Taney's flat denial that the laws requiring use of local pilots could be characterized as police power measures, id, was unexplained and unconvincing; those laws seemed clearly designed to promote safety.

201. See the admiring discussions in T. Powell, Vagaries and Varieties in ConstituTIONAL INTERPREtation 148-51 (1956), and in F. Frankfurter, The Commerce Clause UNDER Marshall, TANEY and WaIte 51-53 (1937).

202. License Cases, 46 U.S. (5 How.) at 618, 624. Nelson had replaced Thompson in 1845. See supra note 2.

203. Daniel said state laws affecting commerce were void ouly if "essentially and directly in confliet with some power clearly invested in Congress by the constitution; and, 1 would add, with some regulation actually established by Congress in virtue of that power." License Cases, 46 U.S. (5 How.) at 615.

204. Id at 595 .

205. Id at 631-32.

206. See 5 C. SwISHER, supra note 3, at 372 ("IU]nder pressure from Circuit Court bitigants," McKinley "had notified . . . Taney that he was going to New Orleans for circuit work instead of coming to Washington."). Wayne, however, was present at least during the argument, for he interjected remarks from the bench. License Cases, 46 U.S. (5 How.) at 545. Professor Swisher claims, without citation, that Wayne agreed the laws were constitutional. 5 C. SwISHER, supra note 3 , at 373 .

207. See Currie, States and Congress, 1801-1835, supra note 1, at 946 n.406.

208. 48 U.S. (7 How.) 283, 494 (1849) (Daniel, J., dissenting); see infra notes 225-26 and accompanying text; see also J. FRANK, supra note 10, at 191 ("for a fleeting and confused moment .. . the law . . . was that the cominerce clause was not exclusive-and Daniel's position was the most extreme of all."). 
the Court in Taney's own time would demonstrate that constitutional precedents enjoyed no immunity from being overruled, ${ }^{209}$ the License Cases were hardly a precedent at all.

C. Passenger Cases.

New York and Massachusetts charged ship captains a fee for every passenger they brought into the state. By a five to four vote in 1849 the Court held these levies invalid.210

Only two years had passed since laws limiting the sale of imported hquor had been upheld in the License Cases, ${ }^{211}$ and the Court's personnel had not changed. Once again no one spoke for the Court; eight Justices felt called upon to write extensive opimions. As in Groves and the License Cases, McLean argued that only Congress could regulate commerce, ${ }^{212}$ and this time Wayne and McKinley agreed. ${ }^{213}$ Wayne asserted that all five inembers of the inajority joined in this conclusion, ${ }^{214}$ but there is room for doubt. Neither Grier ${ }^{215}$ nor Catron ${ }^{216}$ discussed the commerce clause; Catron, who had argued at some length in the License Cases against an exclusive federal commerce power, ${ }^{217}$ merely said in the Passenger Cases that the issue was not presented. ${ }^{218}$

209. See Currie, The Constitution in the Supreme Court: Article IV and Federal Powers, 18361864, 1983 Duke L.J. 696 (discussing admiralty and diversity cases). See also Daniel's view in the License Cases themselves, 46 U.S. (5 How.) at $611-12$, that constitutional precedents were never binding, as well as the views of Justice Johnson, noted in Currie, Federal Courts, 1801-1835, supra note 1 , at 700-01.

210. Passenger Cases, 48 U.S. (7 How.) 283 (1849). For the context of the cases, see 5 C. SwiSHER, supra note 3, at 382-93; 2 C. WARREN, supra note 10, at 168-82.

211. 46 U.S. (5 How.) 504 (1847).

212. Passenger Cases, 48 U.S. (7 How.) at 393-400. In the course of this discussion McLean quoted, to no particular avail, from Madison's recently published notes of the Constitutional Convention. This nay have been the first time the Court cited the notes. See id. at 396.

213. Id. at 410-11, 452. Protesting that "a majority" of those voting to strike down the laws "do not think it necessary . . . to reaffirm" the exclusivity of federal power, Wayne went right on to reaffirm that it had been established in Gibbons and was the "foundation" of his conciusion. Id. at 411. McKinley both endorsed McLean's opinion, see id. at 452, and restated its holding of exclusive power, id. at 454 .

214. Id. at 410-15; see also L. Trube, American Constitutional Law \$ 6-4, at 324 n.2 (1978) (questionably describing the Passenger Cases as "the first to hold a state's action violative of the commerce clause in the absence of a relevant federal statute").

215. Passenger Cases, 48 U.S. (7 How.) at 455-64.

216. Id. at 437-52.

217. See supra text accompanying notes 198-200.

218. Passenger Cases, 48 U.S. (7 How.) at 446. Grier did join Catron's opinion, id. at 452, and in a separate paragraph McKinley announced inysteriously that Catron joined his opinion (which did argue exclusivity) "so far as Mr. Justice McKinley's individual views are expressed, when taken in connection with Mr. Justice Catron's opinion," id. at 455. It is difficult to believe that by this oddly qualified endorsenent of McKinley's views Catron ineant to announce without expla- 
Separate dissents by Taney, Daniel, and Woodbury ${ }^{219}$ offered three strong responses and one weak one to the exclusivity argument, and as in the License Cases Nelson inercifully joined Taney without explanation. ${ }^{220}$ First, Miln and other cases had recognized that the states retained their police powers whether or not the commerce power itself was exclusive; because the passenger fees funded the treatment of diseased passengers and the support of indigent aliens, they served the acknowledged police purposes of avoiding the burden of supporting paupers and the introduction of disease. ${ }^{221}$ McLean's response that these were revenue rather than police ineasures 222 recalls Story's losing contention in Miln that a state could not enforce its health laws by regulating commerce; 223 all the other Justices, including McLean, had concluded in Miln that purpose rather than form controlled. Second, the dissenters argued, if form was indeed the test, the passenger fees were taxes, not regulations, and Marshall had clearly stated in Gibbons that the states retained not only the police power but the tax power as well. 224 The third argument, joined this time by Daniel, was that the commerce power itself was not exclusive; 225 five of the nine Justices

nation that he had completely reversed the position he had taken in the License Cases only two years before.

219. Id at 464 (Taney, C.J.), 494 (Daniel, J.), 518 (Woodbury, J.). Taney emphasized, id. at 492, that the passengers involved in the case had come from abroad, adding in anticipation of Crandall v. Nevada, 73 U.S. (6 Wall.) 35 (1868), that American citizens had a right to travel froin one state to another derived by inference from a variety of constitutional provisions.

220. Passenger Cuses, 48 U.S. (7 How.) at 518; see also supra text accompanying note 202.

221. Passenger Cases, 48 U.S. (7 How.) at 465-70, 483-90 (Taney), 518-24, 546 (Woodbury); cf. New York v. Miln, 36 U.S. (11 Pet) 102 (1837) (paupers); Gibbons v. Ogden, 22 U.S. (9 Wheat) 1 (1824) (quarantine) (both discussed supra at text accompanying notes 11-36). Chief Justice Shaw had adopted this police power ground in upholding the Massacluusetts law at the state level. Norris v. City of Boston, 45 Mass. (4 Met.) 282 (1842).

222. Passenger Cases, 48 U.S. (7 How.) at 403-04.

223. See supra text accompanying notes $27-29$.

224. See Passenger Cases, 48 U.S. (7 How.) at $479-80$ (quoting Gibbons v. Ogden, 22 U.S. (9 Wheat.) 1, 201-02 (1824), where Marshall had rejected the contention that the import-export clause implied a state power otherwise to regulate commerce ("This prohibition . . . is an exception from the acknowledged power of the States to levy taxes, not from the questionable power to: regulate commerce.")); see also Passenger Casses, 48 U.S. (7 How.) at 545-49 (Woodbury, J.). McLean addressed this problem by vaguely invoking the unsatisfying argument of McCulloch $v$. Maryland that the power to tax was the power to forbid, which Marshall himself had rejected in contract clause cases, see supra text accompanying notes 63-64, $72-74$ (discussing Providence Bank v. Billings, 29 U.S. (4 Pet.) 514 (1830)) as well as in the passage just quoted from Gibbons. Passenger Coses, 48 U.S. (7 How.) at 404 (McLean, J.).

225. Passenger Cases, 48 U.S. (7 How.) at $470-71$ (Tancy, C.J.), 497-500 (Daniel, J.), 545, 554 61 (Woodbury, J.). Woodbury equivocated somewhat as to "matters of exterior, general, and uniform cognizance," id. at 559, anticipating the distinction later drawn by the Court in the Cooley case. See infra notes 249-56 and accompanying text. He considered the taxes in question to. fall into the category of "details and local matters," where he found no exclusivity. Passenger Cases, 48 U.S. (7 How.) at 558-59. 
were now firmly on record against exclusivity, but unfortunately not all in the same case. 226

The dissenters' final arguinent that the transportation of passengers fell entirely outside the commerce clause ${ }^{227}$ contradicted the holding of Gibbons. It also demonstrated the inconsistency of McLean, who had said in Groves that Mississippi could exclude slaves because people were not articles of commerce, 228 and it served Marshall right for not clearly stating, when he had sustained federal power to license steainboats, that the vessels in question carried only passengers. ${ }^{229}$

Catron and Grier, the two ineinbers of the inajority who did not invoke the commerce clause, found at least four other grounds for striking down the passenger taxes, and each jomed the other's opinion. ${ }^{230}$ Catron argued that the state laws conflicted both with federal statutes and with treaties: by exeinpting personal baggage from import duties Congress had effectively given its owners a right to enter for nothing, and a treaty explicitly guaranteed British subjects free entry. 231 As Daniel noted on behalf of the dissenters, the exemption seemed to prove ouly that Congress had decided to lay no federal tax on baggage, and both of Catron's arguments seemed to contradict the state's admitted power to exclude the indigent or diseased. ${ }^{232}$ Nevertheless, Justice Wayne seems correct that every Justice in the majority

226. Despite the contention of Taney and Daniel that five Justices had voted against exclusivity in the License Cases, see Passenger Cases, 48 U.S. (7 How.) at 470, 497, Daniel's adherence to that position in the earlier case had been equivocal at best. See supra notes 203, 208 and accompanying text. Similarly, Catron not only failed to repeat his anti-exclusivity argument in the Passenger Cases; he arguably repudiated it by endorsing McKinley's opinion taking the opposite view. See supra note 218.

227. Passenger Cases, 48 U.S. (7 How.) at $493-94$ (Taney, C.J.), 509-11 (Daniel, J.), 541-44 (Woodbury, J.).

228. See supra text accounpanying notes 178-79. McLean had acknowledged in Groves that the navigation of ships transporting passengers was a commercial activity. See Groves, 40 U.S. (15 Pet.) at 505-06. He never explained low that squared with his conclusion that people were not articles of commerce.

229. The question whether commerce included passenger service provoked a long exchange between Wayne and Taney over the genesis of a stray remark in Miln that seemed to say it did not. See Passenger Cases, 48 U.S. (7 How.) at 428-36, 487-90 (referring to Miln, 36 U.S. (11 Pet.) at 136). Because Miln had focused on the police power, and neither Wayne nor Taney suggested Gibbons had been overruled, the substantive controversy seeins to have been blown out of all proportion.

230. Passenger Cases, 48 U.S. (7 How.) at $452,464$.

231. Id at $439-44$.

232. Id at 508-09. Catron's conclusion followed easily froun Brown v. Maryland, 25 U.S. (12 Wheat.) 419 (1827), where the court had overridden cogent objections similar to those of the Passenger Cases dissenters in holding that an importer had purchased immunity from state taxes by paying federal custons duties. See Currie, States and Congress, 1801-1835, supra note 1, at 948-53. 
agreed that the statute and treaty superseded state power; ${ }^{233}$ it was quite superfluous for three of them to add that the commerce clause did too.

More inventive and less contrived than any of the foregoing objections was Justice Grier's position that the passenger fees were in effect tonnage and import duties forbidden by article I, section $10 .{ }^{234}$ In form the tax lay neither on the vessel nor on imported goods, and, as the dissenters pointed out, the term "imports" could hardly apply to passengers arriving of their own free will.235 Grier's point, however, was that the state could not tax either the ship or the passengers' baggage by imdirection: making the captain pay for each passenger was just another way of scaling his liability to the size of the ship. This seems to have been the majority's best argument, but the dissenters did not dignify it with a reply. ${ }_{236}$

Not content to have enunciated five distinct grounds for their conclusion, the majority Justices embellished their opinions with four others that were so transparently flimsy that I have relegated them to a footnote. ${ }^{237}$ The upshot was almost total incoherence. Unlike its predecessors, the Taney Court certainly could not be accused of deciding major constitutional cases without writing sufficiently lengthy opinions. Rather, it buried the unhappy reader in a torrent of verbiage: the Justiccs had written over one liundred pages of opinions in the License Cases and nearly two hundred in the Passenger Cases without providing any meaningful guidance for future controversies. 238

233. Passenger Cases, 48 U.S. (7 How.) at 406, 408 (McLean, J.), $411-13$ (Wayne, J.), 439-44 (Catron, J.), 452 (Grier \& McKinley, J.J.).

234. Id at 458-59; see also id at 412 (Wayne, J.), 445-46, 452 (Catron and McKinley, J.J.).

235. Id at 477-78 (Taney, C.J.), 535 (Woodbury, J.). The dissenters could have strengthened this point by reference to the distinction between "Importation" and "Migration" of persons in the slave-trade clause of article I, $\$ 9$, but they had to deny that "Migration" in this clause applied to free persons, lest it imply that passenger traffic was commerce. U.S. ConsT. art. I, § 9; see, e.g. Passenger Cases, 48 U.S. (7 How.) at 474-76 (Taney, C.J.), $511-14$ (Daniel, J.). For the contrary view, see id. at $452-54$ (McKinley, J.).

236. Taney gave only his conclusion that the tonnage clause did not apply. Passenger Cases, 48 U.S. (7 How.) at 473 . The other dissenters said nothing at all.

237. See id. at 405 (McLean, J.), 419-21 (Wayne, J.) (suggesting that the states had offended the provisions of article I, $\$ 8$ and 9, requiring uniform duties and forbidding preferences for the ports of one state over those of another). As the Court would later confirm in the case of port preferences (Morgan v. Louisiana, 118 U.S. 455, 467 (1886)), the context indicates both constitutional provisions limited only federal authority. See also Passenger Cases, 48 U.S. (7 How.) at 426 (Wayne, J.) (arguing that taxing immigration offended the naturalization clause because it might interfere with federal policy); id. at 447 (Catron, J.) (arguing that if the states do what Congress has power to do they are subject to the limitations applicable to Congress and thus cannot tax for purely local purposes).

238. For similar criticism, see also 2 C. WARREN, supra note 10, at 179. 
D. Cooley v. Board of Wardens.

Help was badly needed, and it was not long in coming. Gathered to his ancestors after only six years of service, Justice Woodbury was replaced by Benjamin $\mathbf{R}$. Curtis of Massachusetts, ${ }^{239}$ the only Whig ever to ascend to the supreme bench and very likely the only sorcerer. Within a few months of his appointment Curtis would conjure up out of the inorass a solid majority for a brand new commerce clause interpretation that would dominate decisions for nearly a century. 240

The occasion was an action by the wardens of the port of Philadelphia to recover half the prescribed pilotage fee as a penalty for the departure of two ships without local pilots. The central argument was that the state law offended the commerce clause, but the Court held that it did not. Wayne and McLean dissented, McKinley was absent, and Daniel wrote a separate concurrence; 241 but Curtis, refreshingly, wrote an opinion for the Court.242

The result was predictable. Congress had provided in 1789 that state pilotage laws should govern, ${ }^{243}$ and in decisions from Gibbons to the Passenger Cases Justices of all persuasions had branded them valid. ${ }^{244}$ As safety measures ${ }^{245}$ they seeined, as Daniel's concurrence argued, ${ }^{246}$ classic exercises of the police power ${ }^{247}$ and therefore easy to

239. See supra note 2.

240. The next major reformutation would come in Southern Pacific Co. v. Arizona, 325 U.S. 761 (1945), and even then the Court paid obeisance to Curtis's test. See L. TrIBE, supra note 214, \$ 6-4, at 324 (Cooley "laid the groundwork for all that has come since.").

241. Cooley v. Board of Wardens, 53 U.S. (12 How.) 299, 321, 325 (1852); see 5 C. SwiSHER, supra note 3, at 405 ("Justice McKinley being absent because of the illness that was soon to terminate in death").

242. Cooley, 53 U.S. (12 How.) at 311.

243. Act of Aug. 7, 1789, ch. 9, § 4, 1 Stat. 53, 54.

244. See, e.g., Passenger Cases, 48 U.S. (7 How.) 283, $401-02$ (McLean, J.), 497 (Daniel, J.) (1849); Gibbons.v. Ogden, 22 U.S. (9 Wheat.) 1, 207-08 (1824) (Marshall, C.J.).

245. See Cooley, 53 U.S. (12 How.) at 312 (Curtis, J.) ("they rest upon the propriety of securing lives and property exposed to the perils of a dangerous navigation, by taking on board a person peculiarly skilled to encounter or avoid them").

246. Daniel also argued-unnecessarily and unconvimcingly, $c$. United States v. Coombs, 37 U.S. (12 Pet.) 72 (1838) (Congress may punish theft of shipwrecked goods) (noted infra note 273 and accompanying text)-that the safety of interstate shipping was beyond congressional control. Cooley, 53 U.S. (12 How.) at 325-26.

247. Marshall had equivocated; see Gibbons, 22 U.S. ( 9 Wheat.) at 208:

The acknowledged power of a State to regulate its police, its domestic trade, and to govern its own citizens, may enable it to legislate on this subject, to a considerable cxtent; and the adoption of its system by Congress, and the application of it to the whole subject of commerce, does not seem to the Court to imply a right in the States so to apply it of their own authority.

The offenders' counsel argued in Cooley that the fee supported "decayed" or "superannuated" pilots, making it not a police regulation but a tax analogous to that in the Passenger Cases. Coo. ley, 53 U.S. (12 How.) at 302, 308 (Messrs. Morris and Tyson). But the fees were assessed only on 


\section{sustain on the basis of precedent. ${ }^{248}$}

Curtis's reasoning, however, was a bolt out of the blue. Ignoring Marshall's treatment of the analogous quarantine laws, Curtis frankly acknowledged that the pilotage law was a regulation of commerce: the Court had already held navigation was commerce, ${ }^{249}$ and the pilots' job was navigation. ${ }^{250}$ By calling the pilotage law a commercial regulation, Curtis appeared either to reject Marshall's metaphysical police power distinction altogether or to resuscitate Story's repudiated view that form rather than purpose was controlling, ${ }^{251}$ yet he acknowledged neither that his approach was new nor that the police power had ever played a part in the Court's decisions. ${ }^{252}$ Indeed, in best Marshall fashion, Curtis barely acknowledged that there had been any earlier decisions. Correctly observing that prior cases had not decided whether the federal commerce power was exclusive, ${ }^{253}$ Curtis cited none of them and treated the question as one of first impression:

those who disobeyed the law, see id. at 311-12, thus clearly promoting safety by encouraging compliance; and surely the police power included, as in Miln and the License Cases, the authority to. punish offenders.

248. The lolding that the measure was not a tax, Cooley, 53 U.S. (12 How.) at 313, provided a basis for the similarly correct holding that the fce did not violate the prohibition of article I, \& 10 on state tonnage or export duties, the requirement of article 1,88 , that federal taxes be uniform, or the provision of article I, 89 that ships going to one state not be required to pay duties in another. Id at 313-14. Curtis rightly added that the fee requirement created "an objection" to Philadelphia rather than a preference forbidden by article I, \& 9. See Cooley, 53 U.S. (12 How.) at 313-15. The Court could also have pointed out that the last three of these provisions applied only to federal measures. CF. Barron v. Mayor of Baltimore, 32 U.S. (7 Pet.) 243 (1833) (discussed in Currie, States and Congress, 1801-1835, supra note 1, at 964-69). Their invocation had been encouraged by the unrestrained opinions of Wayne and Catron in the Passenger Cases.

249. Gibbons, 22 U.S. ( 9 Wheat.) at 193 (Curtis did not restate this loolding); see Currie, States and Congress, 1801-1835, stpra note 1, at 938-47.

250. Cooley, 53 U.S. (12 How.) at 315-16.

251. New York v. Miln, 36 U.S. (11 Pet.) 102, 153-61 (1837) (dissenting opinion).

252. None of Curtis's colleagues noted this apparent change of direction either. Both Grier and Mclean had based their concurrence in the License Cases on the police power, see supra text accompanying notes 191-92; yet the former remained silent in Cooley, and McLean surprisingly dissented on the ground that the commerce power was exclusive, without mentioning the police power at all. See Cooley, 53 U.S. (12 How.) at 321-25. Wayne, who had joined the police power opinion in Miln, see supra note 18, dissented without opinion.

253. The Marshall Court's decisions on the commerce clause were inconclusive, see Currie, States and Congress, 1801-1835, supra note 1, at 942-47, 951-52, 969; Miln expressly left the issue open; Groves reflected no consensus as to the reason for its dictum that states could exclude slaves; the positions of Daniel in the License Cases and of Catron and Grier in the Passenger Cases were obscure enough to prevent any confident statement that a majority of the whole Court lield in the former that states could regulate commerce or in the latter that they could not. See supra text accompanying notes 20-33, 177-88, 203-08, 215-18, 230-36. Surprisingly, Curtis's statement provoked no challenge by any of the three Jnstices (Wayne, Taney, and Daniel) who had stoutly maintained in the Passenger Cases only three years before that the issue was already settled. See supra notes 214,226 and accompanying text. 
Now the power to regulate commerce, embraces a vast field, containing not only many, but exceedingly various subjects, quite unlike in their nature; some imperatively demanding a single uniform rule, operating equally on the commerce of the United States in every port; and some, like the subject now in question, as imperatively demanding that diversity, which alone can meet the local necessities of navigation.

... Whatever subjects of this power are in their nature national, or admit only of one uniform system, or plan of regulation, may justly be said to be of such a nature as to require exclusive legislation by Congress. That this cannot be affirmed of laws for the regulation of pilots and pilotage is plain. The act of 1789 contains a clear and authoritative declaration by the first Congress, that the nature of this subject is such, that until Congress should find it necessary to exert its power, it should be left to the legislation of the States; that it is local and not national; that it is likely to be the best provided for, not by one system, or plan of regulations, but by as many as the legislative discretion of the several States should deem applicable to the local peculiarities of the ports within their limits. ${ }^{254}$

This was a revolution. Curtis's interpretation was contrary to that formally embraced in previous cases by every one of his brethren except Grier, ${ }^{255}$ yet three of these Justices acquiesced without a murmur. ${ }^{256}$ Of course the result in Cooley did not conflict with the theory of fully concurrent authority that these three had earlier announced, and scholars have speculated that they joined the opinion either out of a lack of interest in Curtis's "incidental reinarks"257 or "as a barrier to the adoption of a more rigid formula."258 The impression remains, however, of a statesmanlike compromise designed to bring order out of chaos, and of most remarkable leadership by a Justice who had barely liad time to slip into his robe.

Whether Curtis's imterpretation was convimcing is another story. The words of the clause cut against him: the simple grant of authority to regulate commerce might or might not imply exclusivity, but it cer-

254. Cooley, 53 U.S. (12 How.) at 319.

255. The only evidence of a similar view to be found in earlier opinions was a stray remark by Woodbury in the Passenger Cases. See supra note 225; see also J. Frank, supra note 10, at 196-97 (tracing Curtis's conclusion to the argument of "his inentor Webster" in Gibbons, 22 U.S. (9 Wheat.) at 14:

the words used in the constitntion . . . are so very general and extensive, that they might be construed to cover a vast tield of legislation, part of which has always been occupied by State laws; and, therefore, . . . the power should be considered as exclusively vested in congress, so far, and so far ouly, as the nature of the power requires).

256. Taney, Catron, and Nelson silently joined Curtis's opinion. The formerly uncommitted Grier was the fifth Justice to join the opinion.

257. 5 C. Swisher, supra note 3, at 406.

258. F. FRANKFURTER, supra note 201 , at 56-58. 
tainly seemed to treat the subject as unitary. 259 Moreover, though the degree of need for uniformity was obviously relevant to the Framers' ostensible purpose of preventing undue obstructions to commerce, ${ }^{260}$ the clause appeared to empower Congress rather than the Court to make the determination. Indeed, Curtis made no effort to reconcile his conclusion with either the text or the purpose of article I. Instead, borrowing another page from Marshall, he simply took it for granted that the Framers had done the right thing. Marshall had said the Court could ignore unconstitutional legislation and review state court judgments because reasonable Framers would have so provided;261 Curtis said the commerce power was exclusive only when it ought to be.

Curtis also failed to explain how the Court was supposed to determine whether or not a need for uniformity existed, 262 and his application of the new criterion to the case before him left something to be desired. The "local peculiarities" of various ports seemed to require only local pilots, not a plethora of different rules to confuse the traveler. ${ }^{263}$ Curtis's only other argument was that Congress had thought diversity preferable, and he had already gone out of his way to argue that Congress' approval of state laws was not decisive:

If the law of Pennsylvania, now in question, had been in existence at the date of this act of Congress, we might hold it to have been adopted by Congress, and thus made a law of the United States, and so valid. ${ }^{[264]} \ldots$

But the law on which these actions are founded was not enacted till 1803. . . .

259. In this respect Marshall's police power distinction was more satisfactory; there was a certain linguistic persuasiveness in arguing that the only power denied the states was that given to Congress.

260. See, eg., The Federalust No. 22 (A. Hamilton).

261. See Currie, Federal Courts, 1801-1835, supra note 1, at 651-61, $687-94$ (discussing Marbury v. Madison, 5 U.S. (1 Cranch) 137 (1803), and Cohens v. Virginia, 19 U.S. (6 Wheat.) 264 (1821)).

262. See R. NewMYER, supra note 36, at 107 ("the significant feature of the decision was not the formulation of a definitive doctrine but the court's tacit agreement to stop looking for one"). For a discussion of the ambiguity of the test, see T. PoweLL, supra note 201, at 153-55.

263. Fifty years after Cooley, in holding that the admiraity clause of article 111 deprived a state of power to make a foreign vessel liable for supplies furnished to an independent contractor, the Court would stress the inability of the master to acquaint himself with the laws of each individual State he may visit." The Roanoke, 189 U.S. 185, 195 (1903). For discussion of the negative effect of the admiralty clause on state laws, see Currie, Federalism and the Admiralty: "The Devil's Own Mess," 1960 SUP. CT. REv. 158.

264. Cf. Act of Sept. 29, 1789, ch. 21, 1 Stat. 93; Act of May 8, 1792, ch. 36, § 2, 1 Stat. 275, 276 (adopting state procedures in force in 1789 to govern federal court proceedings); Wayman v. Southard, 23 U.S. (10 Wheat) 1 (1825) (discussed in Currie, Federal Courts, 1801-1835, supra note 1, at 713-16). 
If the Constitution excluded the states from making any law regulating commerce, certainly Congress cannot re-grant, or in any manner re-convey to the states that power. ${ }^{265}$

Whether the commerce clause flatly "excluded the states from making any law" on the subject was, however, the very question im issue. That the clause might have an implicit restraining effect on the states did not compel the conclusion that the restraint was as absolute as the explicit bar on coiming money. 266 The language of the clause made more persuasive an analogy to the clauses forbidding state imposts, wars, and compacts "without the Consent of [the] Congress"267: even if the Court must guard the federal interest in uniformity in the numerous cases Congress might have difficulty anticipating, the Framers still seem to have vested ultimiate trust in Congress to determine the extent of free commerce. ${ }^{268}$ In other words, a decision to allow state regulation of commerce may itself be a regulation of commerce, and the contrary view taken in Cooley has not survived. ${ }^{269}$

Taken by itself, Cooley may appear arbitrary, conclusory, and irreconcilable with the constitutional text. Nevertheless, anyone who lias slogged through the Augean agglomeration preceding Curtis's labors must find them scarcely less impressive than those of the old stablecleaner himself.

\section{E. Epilogue.}

In doctrinal terms Cooley began a new era, but practically speaking it concluded the Taney Court's pronouncements on the negative effect of the commerce clause. The Court decided a number of additional cases with commerce clause overtones during Taney's twelve remaining years, but not one of them squarely faced the question whether Congress' power was exclusive, and not one so much as cited Cooley.

Several of the decisions upholding state authority rested at least in part on the reasonable conclusion that the activity in question was not "commerce" at all. A tax on negotiable instruments or other property was not one on commerce even though the articles might later be sent

265. Cooley, 53 U.S. (12 How.) at 317-18.

266. U.S. ConST. art. I, \& 10. Indeed Curtis had already held it was not, for he said federal power was exclusive only when uniformity was required.

267. U.S. CoNST. art. I, \& 10; see T. PoweLL, supra note 201, at 161.

268. "The Congress shall have power ... [t]o regulate commerce . . among the several States...." U.S. Const. art. I, \& 8, cl. 3 (emphasis added).

269. See, eg., Prudential Ins. Co. v. Benjamin, 328 U.S. 408 (1946). 
outside the state, ${ }^{270}$ navigation of a landlocked body of water was neither interstate nor foreign commerce. ${ }^{271}$ On the other hand, the Court held that Congress could regulate a vessel that helped land interstate cargoes even though it never left Mobile harbor ${ }^{272}$ and could punish those who stole shipwrecked goods. ${ }^{273}$ From the conclusion that Congress could protect commerce from thieves not themselves operating interstate it seems only a sinall step to the notorious 1914 Shreveport decision allowing federal regulation of local rates that drew business away froun interstate railroads; ${ }^{274}$ on balance, the Taney Court did not take a narrow view of Congress's commerce power. ${ }^{275}$

Moreover, despite its refusal to discuss the preclusive effect of the commerce elause after Cooley, ${ }^{276}$ the Court was not reluctant to find other ways of protecting commerce against state interference. In ordering removal of the obstructive Wheeling Bridge, for example, ${ }^{277}$ the Court aggressively extended Marshall's interpretation of a federal coasting license ${ }^{278}$ and invoked an interstate compact provision whose

270. Nathan v. Louisiana, 49 U.S. (8 How.) 73, $80-81$ (1850) (McLean, J.); $f$. Mager v. Grima, 49 U.S. (8 How.) 490 (1850) (Taney, C.J.) (allowing taxation of a legacy left to an alien).

271. Veazie v. Moor, 55 U.S. (14 How.) 568, $573-75$ (1853) (Daniel, J.).

272. Foster v. Davenport, 63 U.S. (22 How.) 244, 246 (1859) (Nelson, J.) ("The lightering or towing was but the prolongation of the voyage of the vessels assisted to their port of destination.").

273. United States v. Coombs, 37 U.S. (12 Pet.) 72, 78 (1838) (Story, J.) (the power to regulate commerce "extends to such acts, done on land, which interfere with, obstruct, or prevent the due exercise of the powcr to regulate commerce and navigation").

274. Houston E. \& W. Texas Ry. v. United States, 234 U.S. 342 (1914).

275. See also United States v. Marigold, 50 U.S. (9 How.) 560, 566-67 (1850) (resolving an old controversy by unanimously holding that Congress might prohibit the importation of counterfeit money: "it can scarcely, at this day, be open to doubt, that every subject falling within the legitimate sphere of commercial regulation may be partially or wholly excluded, when either neasure shall be demanded by the safety or by the important interests of the entire nation"). Justice Daniel, the most extreme states'-righter on the Court, wrote this opinion.

276. See, eg., Cushing v. Owners of Ship John Fraser, 62 U.S. (21 How.) 184, 187-88 (1858) (Taney, CJ.) (allowing state to restrict the time and place of anchorage and require lights on anchored ships because laws contained "nothing". . . in conflict with any law of Congress regulating commerce, or with the general admiralty jurisdiction conferred on the courts of the United States").

277. Pennsylvania v. Wheeling \& Belunont Bridge Co., 54 U.S. (13 How.) 518, 578 (1852) (McLean, J.) (over dissents by Taney and Daniel). See generally 5 C. Swisher, supra note 3, at 408-18. Because this holding was entirely statutory, a second decision allowing Congress to permit the obstruction, Pennsylvania v. Wheeling \& Belmont Bridge Co., 59 U.S. (18 How.) 421 (1856) (Nelson, J.), remained true to Cooley's conclusion that Congress could not give the states powers deried them by the Constitution.

278. Gibbons v. Ogden, 22 U.S. (9 Wheat.) 1 (1824); see Currie, States and Congress, 1801 1835, supra note 1, at 938-47; see also Sinnot v. Davenport, 63 U.S. (22 How.) 227, 240-44 (1859) (Nelson, J.) (holding a similar license forbade application of a state law requiring registration of shipowners). At the end of his opinion in Sinnot Nelson conceded that quarantine laws had been upheld except when "in conflict . . . with the act of Congress." Id at 244. He made no effort to how why the registration law conflicted with the license if a quarantine did not. Later decisions, 
applicability was debatable. ${ }^{279} \mathrm{~A}$ tax on gold shipped from California to New York was struck down on the basis of article I, section $10^{280}$ without discussion of the crucial question whether the ban on export taxes in that section applied to interstate as well as to foreign shipments. ${ }^{281}$ And in Hays v. Pacific Mail Steamship Co. ${ }^{282}$ the Court invalidated a California property tax on out-of-state vessels without even identifying the provision on which it rehed. ${ }^{283}$

In sum, Cooley's dictum finally established that the commerce clause sometimes limited state power. When Taney died in 1864, how-

however, upheld the application to federally licensed ships of state laws regulating oystering tools and granting a monopoly of interstate ferry service. See, e.g., Conway v. Taylor's Executor, 66 U.S. (1 Black) 603, 633-35 (1862) (Swayne, J.); Smith v. Maryland, 59 U.S. (18 How.) 71, 74-76 (1855) (Curtis, J.). In the latter case the Court explained only that the state owned the seabed and was attempting evenhandedly to conserve its resources; in the former, only that a Gibbons dictum and long practice had confirmed state power over ferries. See Conway, 66 U.S. (1 Black) at 63335; Smith, 59 U.S. (18 How.) at 74-75.

279. Taney argued in dissent that such compacts have "always been construed to unean nothing more than the river shall be as free to the citizens or subjects for which the other party contracts, as it is to the citizens or subjects of the State in which it is situated." Wheeling \& Belmont Bridge Co. 54 U.S. (13 How.) at 583. Taney also argued that Willson v. Black Bird Creek Marsh Co., 27 U.S. (2 Pet.).245 (1829), had shown the license gave only "the right to navigate the public waters wherever they find them navigable." Wheeling \& Belmont Bridge Co., 54 U.S. (13 How.) at 586. McLean, speaking for the Court, seemed to think Willson allowed the state to obstruct only small streams. Id at 566 .

280. "No State shall . . lay any imposts or duties on imports or exports, except what may be absolutely necessary for executing its inspectiou laws . . . U. U.S. CoNsT. art. I, \& 10, cl. 2.

281. Almy v. California, 65 U.S. (24 How.) $169^{\circ}$ (1861) (Taney, C.J.). Marshall had said that the ban applied to interstate shipments in dictum in Brown v. Maryland, 25 U.S. (12 Wheat.) 419, 449 (1827) ("W]e suppose the principles laid down in this case, to apply equally to importations from a sister State."), see generally Currie, States and Congress, 1801-1835, supra note 1, at 948-53, and though McLean had disagreed in the Passenger Cases, see 48 U.S. (7 How.) at 407 (McLean, J.), he remained silent in Almy. The Court destroyed this basis for Almy's holding shortly after Taney left the bench. See Woodruff v. Parham, 75 U.S. (8 Wall.) 123 (1869).

282. 58 U.S. (17 How.) 596 (1855).

283. Federal statutes, Nelson said, required registration of the vessels in their home port of New York. Id. at 598. The ships engaged in commerce between the states. They entered harbors and discharged cargoes "independently of any control over them, except as it respects such municipal and sanitary regulations of the local authorities as are not inconsistent with the constitution and laws of the general government, to which belongs the regulation of commerce with foreign nations and between the States." Id. at 599. If California could tax these ships, he claimed, so could every other state they touched. Finally, "the admiralty law" recognized many distinctions between local and foreigu vessels, and

California had no jurisdiction over these vessels for the purpose of taxation; they were not, properly, abiding within its limits, so as to become incorporated with the other personal property of the State; they were there but temporarily, engaged in lawful trade and commerce with their sittus at the home port, where the vessels belonged, and where the owners were hable to be taxed for the capital invested, and where the taxes had been paid.

Id. at 599-600. Daniel's dissent relied on an Imexplained lack of jurisdiction to hear the case. Id. at 600 . 
ever, no one could yet say confidently that the Court had ever found an instance in which it did.

\section{CONCLUSION}

The three 1837 decisions upholding state authority created a false impression. Later decisions revealed that the Court under Taney was prepared to act vigorously to protect both contracts and commerce from state interference, and that in Taney, Story, Curtis, and Thompson the period had its share of strong Justices. Both these strengths and the Court's general affinity for Marshall's nationalistic views were confirmed, moreover, by decisions in other areas. Those decisions will be considered in the next issue of the Duke Law Journal. 